\title{
Monetary Policy and Racial Inequality
}

Alina K. Bartscher | Moritz Kuhn | Moritz Schularick | Paul Wachtel 


\title{
Monetary policy and racial inequality *
}

\author{
Alina K. Bartscher ${ }^{\dagger} \quad$ Moritz Kuhn ${ }^{\ddagger}$ \\ Moritz Schularick ${ }^{\S}$ Paul Wachtel ${ }^{\mathbb{I I}}$
}

January 2021

\begin{abstract}
This paper aims at an improved understanding of the relationship between monetary policy and racial inequality. We investigate the distributional effects of monetary policy in a unified framework, linking monetary policy shocks both to earnings and wealth differentials between black and white households. Specifically, we show that, although a more accommodative monetary policy increases employment of black households more than white households, the overall effects are small. At the same time, an accommodative monetary policy shock exacerbates the wealth difference between black and white households, because black households own less financial assets that appreciate in value. Over multi-year time horizons, the employment effects are substantially smaller than the countervailing portfolio effects. We conclude that there is little reason to think that accommodative monetary policy plays a significant role in reducing racial inequities in the way often discussed. On the contrary, it may well accentuate inequalities for extended periods.
\end{abstract}

Keywords: monetary policy, racial inequality, income distribution, wealth distribution, wealth effects

JEL classification codes: E40, E52, J15

${ }^{\star}$ We are grateful to Klaus Adam, Adrien Auclert, Ellora Derenoncourt, Michael Fleming, Jordi Galí, Ethan Ilzetzky, Chi Hyun Kim, Anna Kovner, Alexander Kriwoluzky, Keith Kuester, Emanuel Mönch, Gernot Müller, Emil Holst Partsch and Pascal Paul for comments and suggestions. The views expressed herein are solely the responsibility of the authors and should not be interpreted as reflecting the views of the Federal Reserve Bank of New York or the Federal Reserve System. Dean Parker, Francisco Ruela and Siddhi Jagdale provided excellent research assistance. All errors are our own. The project received support from the Deutsche Forschungsgemeinschaft (DFG) under Germany's Excellence Strategy - EXC 2126/1 - 39083886.The paper has benefited from a visit by Paul Wachtel as a fellow at the Frankfurt Center for Advanced Studies: Foundations of Law and Finance funded by the German Research Foundation (Deutsche Forschungsgemeinschaft, DFG) project FOR 2774.

${ }^{\dagger}$ Department of Economics, University of Bonn (alina.bartscher@uni-bonn.de).

‡Department of Economics, University of Bonn; CEPR and IZA (mokuhn@uni-bonn.de).

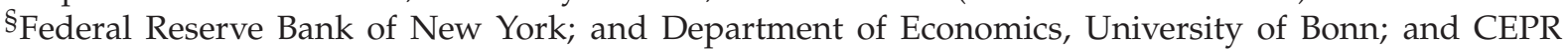
(moritz.schularick@ny.frb.org; schularick@uni-bonn.de).

IIDepartment of Economics, New York University Stern School of Business (pwachtel@stern.nyu.edu). 
"The Fed has a profound impact on our economy. ... [it] promotes maximum employment, and stable prices.... the Fed should add to that responsibility, and aggressively target persistent racial gaps in jobs, wages, and wealth..."

Joseph Biden, Wilmington, Delaware, July $28,2020^{1}$

\section{INTRODUCTION}

The racial tensions that have spread across the United States in 2020 have caught the attention of monetary policymakers. Fifty years past the accomplishments of the civil rights movement, racial gaps in income and wealth remain enormous. The size and persistence of the gap between both the income and wealth of black and white households has recently attracted much attention (Chetty et al., 2020; Emmons, 2020). There is widespread recognition that - despite some decline in overt labor market discrimination and gains in educational opportunities and income growth of black households since the onset of the Civil Rights movement - the gaps persist and have even grown larger by some measures (Kuhn, Schularick, and Steins, 2020). According to the 2019 Survey of Consumer Finances (SCF), the median household wealth of a white household was $\$ 184,390$, compared to only $\$ 20,730$ for the median black household. The typical black household owns only about $11 \%$ of the wealth of the typical white household. The income gap is smaller but still large; the median income of black households $(\$ 38,688)$ is 58 percent of the median income of white households $(\$ 67,196)$.

Some central bankers argue that the Federal Reserve can play a role in addressing racial inequalities. Raphael Bostic, president of the Federal Reserve Bank of Atlanta, recently stated that the Federal Reserve "can play an important role in helping to reduce racial inequities and bring about a more inclusive economy." ${ }^{2}$ A prominent line of thinking runs as follows: A more accommodative policy lowers unemployment and increases labor income for workers who would otherwise have become unemployed, or stayed unemployed for longer. Marginal workers that are drawn into the labor market by more accommodative policies are oftentimes low-income and minority households. Consequently, the gap

\footnotetext{
${ }^{1}$ https://www.rev.com/blog/transcripts/joe-biden-racial-equity-plan-speech-transcript-july28

${ }^{2}$ https://www.frbatlanta.org/about/feature/2020/06/12/bostic-a-moral-and-economicimperative-to-end-racism
} 
between unemployment rates of black and white households narrows. ${ }^{3}$

In their study of the distributional effects of monetary policy, Coibion et al. (2017) refer to this effect on low-income workers as the earnings channel. Yet at the same time, monetary policy has portfolio effects through its impact on the prices of assets. Asset price changes affect the wealth distribution if household portfolios differ systematically between black and white households. Using SCF data, we will show that this is a very pronounced fact in the data: black households hold substantially different portfolios and in particular less financial assets than white households so that monetary policy potentially has larger effects on white households' portfolios. Further, the median black household has no stock holdings, nor owns a house. By definition, any effect that monetary policy has on the price of such assets bypasses the majority of black households.

This opens the possibility that the portfolio effects of more accommodative policy go in the opposite direction to the earnings effects, at least at a business cycle frequency. In other words, more accommodative monetary policy could benefit black households by reducing unemployment and increasing labor market participation and earnings, thereby helping to reduce the racial income gap - and over time also the wealth gap, if part of the additional income is saved. But the same policies could widen racial wealth differences if white households benefit more from rising asset prices than black households due to their different portfolio composition and greater wealth.

Whether this is the case is largely an empirical question at this stage. By design, the impact of monetary policy on different parts of the population could not be studied in traditional macroeconomic models with representative agents. More recently, models have begun to take distributional effects of monetary policy more seriously, including the asset price channel of monetary policy transmission (Auclert, Rognlie, and Straub, 2020), and its effect on risk premia (Kekre and Lenel, 2020). In current state-of-the-art models with heterogeneous agents, monetary policy can have differential impacts on specific groups, as transmission no longer exclusively takes place through intertemporal substitution. In such models, economic agents are affected differentially by monetary policy, and differences in asset portfolios (portfolio heterogeneity) are an important channel for such effects (Kaplan, Moll, and Violante, 2018). We will show that such portfolio heterogeneity between black and

\footnotetext{
${ }^{3}$ This channel is often emphasized in policy discussions (Aliprantis and Carroll (2019) and there is evidence (Carpenter and Rodgers, 2004; Rodgers, 2008) that an accommodative policy reduces the racial gap in the unemployment rate. In the words of Atlanta Fed President Bostic (see footnote 2): "The Federal Reserve acts to create a foundation upon which businesses, families, and communities can thrive. Our success means that businesses can grow faster and hire more workers and that more innovation can be supported, which would mean more opportunities for African Americans and others who have not been as attached to the economy."
} 
white households is a strong empirical fact. Heterogeneous agent models could therefore have important implications for the study of racial inequality. 4

In this paper, we quantify and compare the size of both the earnings and portfolio effects of monetary policy in a unified empirical framework and find evidence that both effects are at play. We use instrumental variable local projections (LP-IV) following Stock and Watson (2018) and Jordà, Schularick, and Taylor (2020) to study the effect of monetary policy shocks on both asset prices and black-white employment gaps over five-year horizons. To infer portfolio effects on the wealth distribution, we first study how monetary policy affects the price of houses, equities, and other financial assets. We then link these estimated asset price changes to the portfolio composition of white and black households using the comprehensive wealth data from the most recent wave of the SCF in 2019, and determine the effect on black (white) households' net wealth.

For the empirical analysis, this paper relies on the most widely used monetary policy shock series - the (extended) Romer-Romer shocks (Coibion et al., 2017) as well as different financial market surprise measures taken from Bernanke and Kuttner (2005) and Gertler and Karadi (2015). The estimations yield a consistent result. Over a five-year horizon, accommodative monetary policy leads to larger employment gains for black households, but also to larger wealth gains for white households. More precisely, the black unemployment rate falls by about 0.2 percentage points more than the white unemployment rate after an unexpected 1oobp monetary policy shock. But the same shock pushes up stock prices by as much as $5 \%$, and house prices by $2 \%$ over a five-year period, while lowering bond yields on corporate and government debt and pushing up inflation. The sustained effects on employment and stock and house prices appear to be a robust feature in the data, across different shock specifications, estimation methods, and sample periods.

Importantly, the employment and income gains of black households are small compared to the wealth gains of white households. Specifically, we find that a typical accommodative monetary policy shocks leads to capital gains from asset price changes of about $\$ 25,000$ to $\$ 35,000$, equivalent to 20-30 percent of the mean income of white households (and close to half of median income). By contrast, the wealth gain that black households experience is substantially smaller, about $\$ 5, \mathrm{ooo}$, or 10 percent of annual income. The larger capital

\footnotetext{
${ }^{4}$ Heterogeneous agent models such as Kaplan, Moll, and Violante (2018), Bayer et al. (2019), Luetticke (2018) and Kekre and Lenel (2020) are not yet able to capture the full complexity of the differences in portfolio structure between black and white households. There are models with heterogeneous agents that address distributional effects in a formal general equilibrium context (e.g. Auclert (2019), Gornemann, Kuester, and Nakajima (2016) and Luetticke (2018)). These models are important advances, although there is uncertainty regarding model specifications. None of these papers addresses racial inequality.
} 
gains for white households mainly stem from the stock market, as most stocks are owned by white households. Although housing is much more equally owned, capital gains from the housing market still fall disproportionately on white households.

Taken together, the effects of accommodative monetary on the wealth of black and white households are comparatively large, while the effects on employment are comparatively small, highlighting the trade-off between racial income and wealth inequality for monetary policymakers. Put differently, an accommodative monetary policy would need to have a much larger effect on black unemployment and income than what is typically estimated in order to offset the impact of even modest changes in asset prices on wealth. Thus, we will suggest that there is little reason to think that "easy" monetary policy can play a significant role in reducing racial inequities in the way currently discussed. By some measures, it might even lead to a deterioration.

The structure of this paper is as follows. In Section 2, we discuss racial inequalities in income and wealth, present the data and discuss the background literature. We present our estimates of the effects of monetary policy shocks on asset prices and the unemployment gap in Section 3. Finally in Section 4, we examine the impact of a typical monetary policy on black and white wealth and compare the wealth effect to the earnings effects. The last section concludes.

\section{RACIAL INEQUALITIES IN INCOME AND WEALTH}

Racial inequalities in income and wealth in the United States remain enormous. In 2019, the median household wealth of a white household was almost nine times higher than for black households while white median income was 1.7 times larger than for blacks according to data from the 2019 Survey of Consumer Finances (SCF). Not only is the wealth gap between black and white households large, it has hardly changed over the last 50 years since the onset of the civil rights movement. Large racial income and wealth gaps are not a recent phenomenon but their persistence over the modern history of the United States is striking. In this section, we present key trends and show the strong portfolio heterogeneity between black and white households. 


\subsection{SCF data}

The SCF provides representative household-level data on the financial situation of U.S. households. The SCF employs a particular survey design to oversample wealthy households that allows researchers to study the entire U.S. wealth and income distribution, including the richest households (Bricker, Dettling, et al. (2017); Bhutta, Bricker, et al. (2020); Kuhn, Schularick, and Steins (2020). The detail of the financial information, the data quality, and the extent of the household coverage have made the SCF the primary source for the study of the income and wealth distribution of U.S. households.

We focus on black and white households according to the answers of household heads in the SCF interview. In the 2019 SCF data, $68 \%$ of household heads reported being white, $16 \%$ answered being non-black and non-white, and $16 \%$ of households answered that they have a black household head. For our analysis, we ignore households who report having a non-black non-white head. 5

For the purpose of our study, the representative coverage of the wealthiest households is important for studying the redistributive consequences of monetary policy. Kuhn and Ríos-Rull (2016, updated) document that the richest 10\% of U.S. households today own more than $75 \%$ of all wealth and that this group is overwhelmingly non-black, with less than $3 \%$ of these households having a black household head. For our analysis, we follow the definitions for income and wealth as in the previous literature (Bricker, Henriques, et al. (2016); Kuhn and Ríos-Rull (2016); Kuhn, Schularick, and Steins (2020)).

We construct wealth as the sum of all assets minus all debt of a household. We consider marketable wealth so that we do not include claims against social security or defined-benefit retirement plans. Defined-contribution retirement plans are part of marketable wealth and constitute $17 \%$ of wealth in the United States (Kuhn and Ríos-Rull, 2016). Housing includes the primary residence, other residential real estate, and the net value of non-residential real estate. For income, we consider income from all sources; for earnings, we use wage and salary income. We convert all nominal variables throughout the paper to 2019 dollars using the CPI deflator.

We use the approach of Bricker, Dettling, et al. (2017) to construct household holdings of all asset classes, constructing total stock and bond positions as the sum of direct and indirect holdings. Directly held bond and stock investments are allocated to their respective ${ }^{5}$ The SCF convention is that in a couple the male spouse is the household head and we follow this convention
in our analysis. 
positions. For indirect holdings, we allocate stock and bond investment components for stock and bond mutual funds, annuities and trusts, retirement accounts and investment savings accounts to the respective total stock and bond holdings. In the end, total stock holdings are the sum of directly held stocks, stock mutual funds, where we take $50 \%$ of the holdings of combination mutual funds, and the share of retirement plans, other managed investments and investment saving accounts which are invested in stocks, as reported by the survey participants. We proceed accordingly for bonds.

\subsection{Trends in racial income and wealth inequality}

Table 1 provides a summary of the financial situation of black and white households in the United States in 2019. We report several asset components from household balance sheets, as well as total debt, wealth, and income. For each variable, we report means and medians. The descriptive statistics document the large racial gap between households for both income and wealth.

The SCF data show that the average black household has $5^{1}$ cents for each dollar of white household income. The average wealth gap is dramatically larger; the average black household had only 15 cents per dollar of white household wealth. The racial wealth gap is

Table 1: Mean and median black and white wealth and income

\begin{tabular}{lrrrrrr}
\hline & \multicolumn{2}{c}{ Means } & \multicolumn{2}{c}{ Medians } & \multicolumn{2}{c}{$\begin{array}{c}\text { Share with } \\
\text { holdings (\%) }\end{array}$} \\
& White & Black & White & Black & White & Black \\
\hline Bonds & 122378 & 19609 & 0 & 0 & 47 & 27 \\
Housing & 353513 & 104694 & 170000 & 0 & 75 & 46 \\
Equity & 473986 & 40927 & 9000 & 0 & 64 & 35 \\
Other non-financial assets & 33391 & 13519 & 17000 & 8000 & 90 & 72 \\
Liquid assets & 57016 & 13856 & 8000 & 1430 & 99 & 95 \\
Other financial assets & 39473 & 11806 & 0 & 0 & 39 & 31 \\
\hline Net wealth & 973489 & 148139 & 184390 & 20730 & & \\
Debt & 106269 & 56272 & 32200 & 10000 & & \\
Income & 113336 & 58095 & 67196 & 38688 & & \\
\hline
\end{tabular}

Notes: The table shows mean and median wealth components and incomes, as well as the share of households with positive holdings of each asset category, for black and white households. 
prevalent on the entire household balance sheet but it is much smaller for non-financial assets. For example, for housing, the average black household owns 30 cents per dollar of the average white household. By contrast, if we look at equities, black households hold on average only 9 cents for every dollar of equity holding by white households.

Comparing means and medians highlights the large skewness of the U.S. wealth distribution, with means being much larger than medians. For example, the racial wealth gap is larger at the median than at the mean. ${ }^{6}$ For many asset types, the median holding is zero or close to zero because the share of households with holdings is small. Only 35 percent of black households own equities, just a bit more than half the share of white households. Many black households in the United States do not have any financial assets and if asset prices increase, such poor households will not benefit from this rise. Black households are heavily underrepresented at the top of the U.S. wealth distribution, where financial wealth is heavily concentrated. Their financial situation is therefore generally very similar to the wealth situation of the typical poor American households.

Kuhn, Schularick, and Steins (2020) compiled household-level data from early waves of SCF data to examine the financial situation of U.S. households going back to 1950. Using these data, Figure 1a shows three-wave moving averages of the racial wealth gap, i.e., the ratio of average black to average white wealth. Figure $1 b$ shows analogous results for income. 7 The data suggest a secular inverted U-shape for the racial wealth gap. The racial wealth gap was smallest in the 1970s, at the top of the inverted $U$, and it was largest in the aftermath of the financial crisis, when the racial wealth gap grew back to levels not seen since the 1950 . Wolff (2016) and Kuhn, Schularick, and Steins (2020) document that the collapse of house prices was a key driver of this widening wealth gap after the financial crisis. However, looking at the longer run, the data show a secular widening of the racial wealth gap that started in the 1980s and accelerated in the 2000s. The trends in the income gap are similar. There was a dramatic reduction in racial income inequality in the 1960s and 1970s which was followed by a rapid return to earlier levels of the gap. ${ }^{8}$

\footnotetext{
${ }^{6}$ Medians are computed within asset classes and might therefore not correspond to the asset holdings of the median-wealth household.

7The data are winsorized at the 98th percentile within each year-race bin because there are some extreme outliers in the historical data due to small sample sizes and imputations.

${ }^{8}$ The gap in median incomes is different; median income inequality is reduced since the 1990s, although the gap is still larger than in the late 1970s.
} 
Figure 1: Long-run trends of the racial wealth and income gaps (moving average)
(a) Wealth
(b) Income
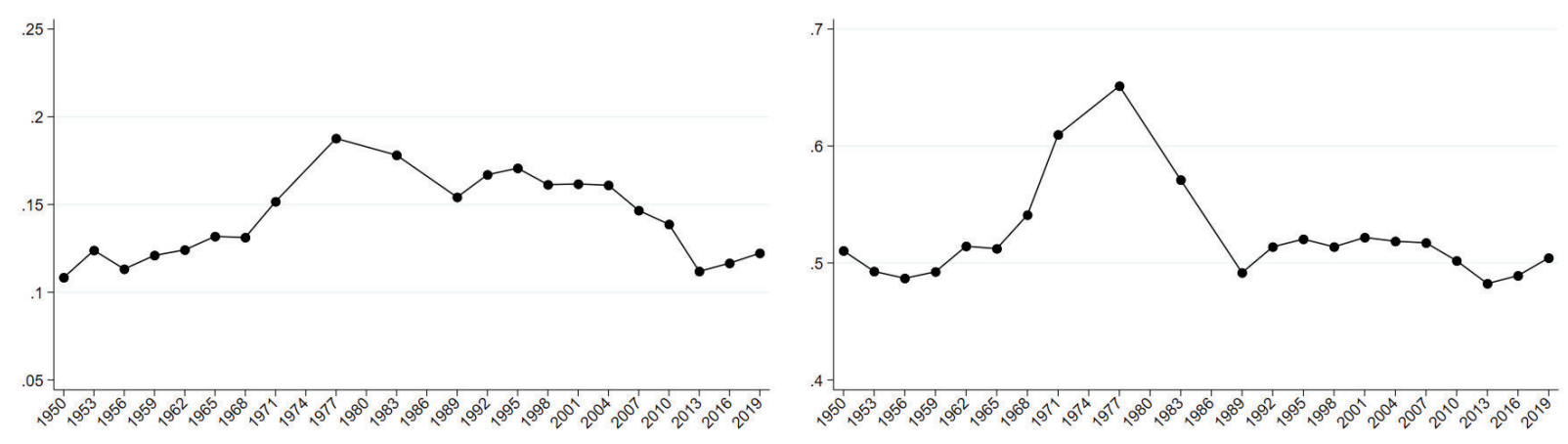

Notes: The left panel shows the evolution of the ratio to average black to average white wealth over time. The right panel shows the evolution of the ratio to average black to average white income over time. The data were winsorized at the 98th percentile within each year-race bin and smoothed by taking a moving average across three neighboring waves.

In Figure 2a, we contrast the dollar changes in average wealth levels of black and white households in the United States over the past 70 years relative to 1971. While average white wealth increased by well over half a million dollars in today's dollars, the wealth of black households increased by about 100,000 dollars, keeping the wealth gap at roughly the same level as in the 1950s. The stock market boom of the 1990s provided a large boost to white wealth, which increased by about 400,000 dollars per household within a decade, while average black wealth increased by less than 10,000 dollars. Such large differences stem from the much higher exposure to equity markets of wealthy, typically white, U.S. households. Yet, it must be kept in mind that also among white households, such increases in equity prices as during the 1990 also tend to increase wealth inequality (Kuhn, Schularick, and Steins, 2020). 
Figure 2: Change in wealth and wealth-to-income ratios relative to 1971

(a) Wealth change

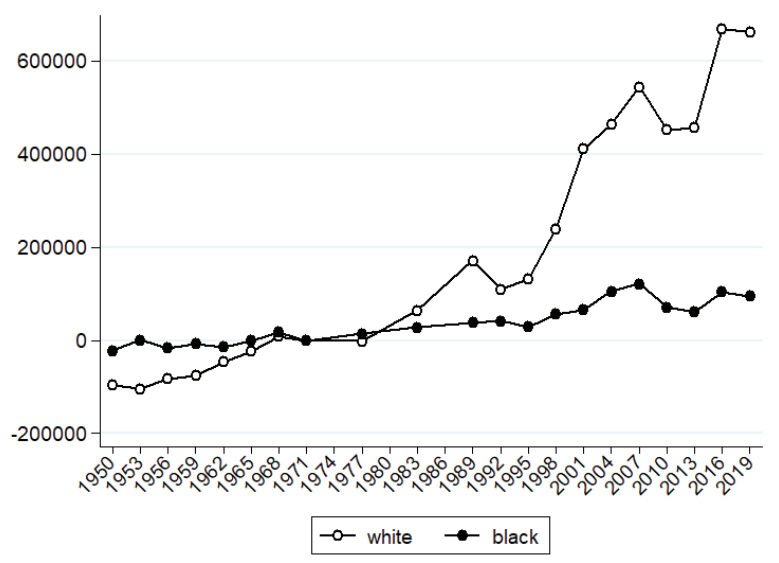

(b) Change of wealth-to-income ratios

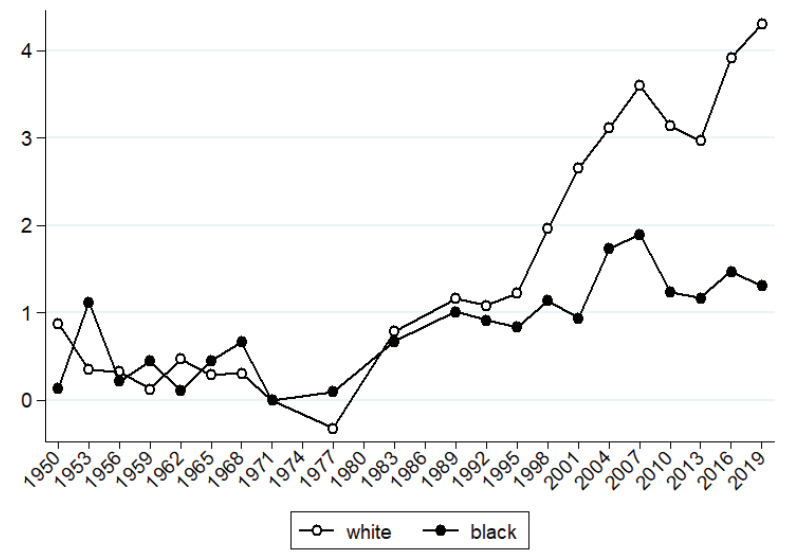

Notes: The left panel shows the evolution of average black and average white wealth over time, normalized by subtracting 1971 averages for each group. The right panel shows the evolution of average black and average white wealth-to-income ratios over time, normalized by subtracting 1971 averages for each group. All data are in 2019 dollars.

Large wealth gains from asset prices also drive a wedge between income and wealth dynamics. Figure $2 \mathrm{~b}$ therefore compares the changes in wealth-to-income ratios of black and white households relative to 1971. We find a strong co-movement from the early 1950 s to the mid-1990s when a rapid divergence took place. By 2019 (see Table 1), white households owned 8.6 dollars of wealth per dollar of income, while black households own only 2.5 dollars of wealth per dollar of income. Over the 40-year time period from 1980 to today and when taking the racial income gap into account, we still find that black households increased their wealth by only about one year's income while the wealth of white households increased by about four times their annual income. These large racial gaps become important when considering the effect of asset prices. High wealth-to-income ratios imply that changes in asset prices lead to large wealth gains relative to income, so that differences in saving rates operating on income flows can have only a small impact on the wealth gap compared to the impact of asset price changes operating on much larger wealth stocks.

Besides the large wealth and portfolio differences between black and white households in the United States, a large gap in unemployment rates is another defining feature of the economic situation of black and white households. This racial unemployment gap is the focus of discussions of the earnings effect of monetary policy. We use Bureau of Labor Statistics (BLS) data on unemployment rates starting in 1972 when the black unemployment 
rate data comes available. ${ }^{9}$ Figure 3 shows the time series for the black-white unemployment rate gap from 1972 to 2020 .

Figure 3: Unemployment rate gap

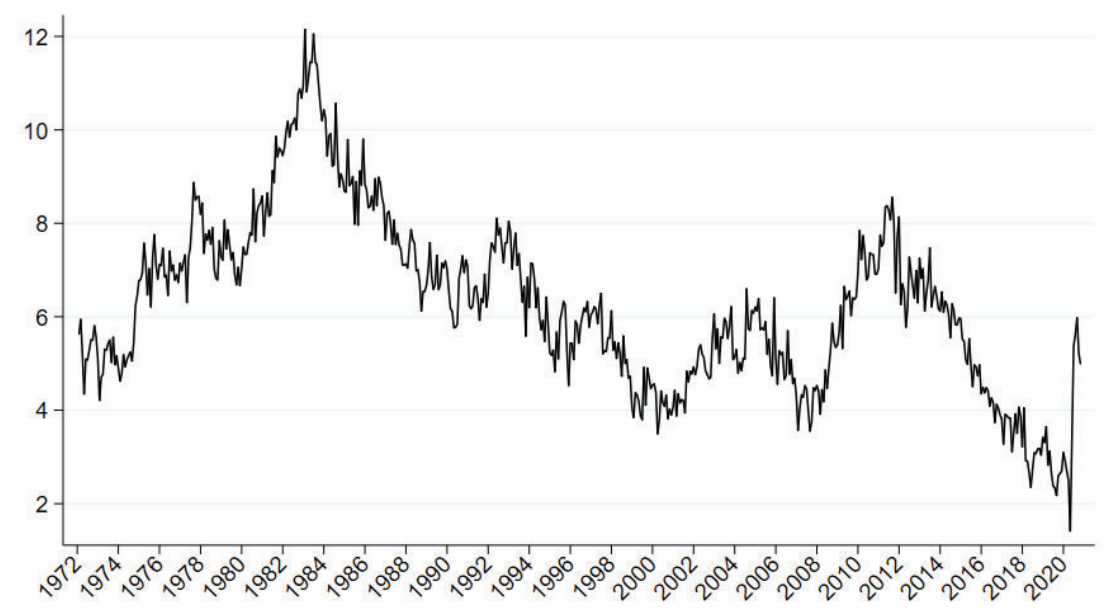

Notes: The graph shows the difference between the black unemployment rate and white unemployment rate after seasonal adjustment with Census X-12 ARIMA.

The racial unemployment gap varies between 12 percentage points during the 1982 recession and less than 2 percentage point in the tight labor market at the beginning of 2020 . The time series show some clear countercyclical pattern with the unemployment gap increasing in recessions and falling during business cycle expansions. With exception of the last decade, the unemployment gap between black and white workers was large, fluctuating around 6 percentage points for four decades.

\subsection{Household portfolios and asset price changes}

The asset holdings of average black and white households in Table 1 already highlight the large differences in portfolio composition between the average black and white household. Figure 4 displays the relative portfolio composition by showing the shares of total assets for each category for black and white households. The two dominant portfolio components are housing and equity, where equity includes direct and indirect stock holdings. White households hold $33 \%$ and $44 \%$ of their assets in housing and equity, respectively, while the corresponding figures for black households are $51 \%$ and $20 \% .{ }^{10}$

These differences in portfolio composition translate into differences in exposure of house-

${ }^{9}$ The gap is the difference between black and white unemployment rates where the data are seasonally 
Figure 4: Portfolio composition of white and black households (percent of total)

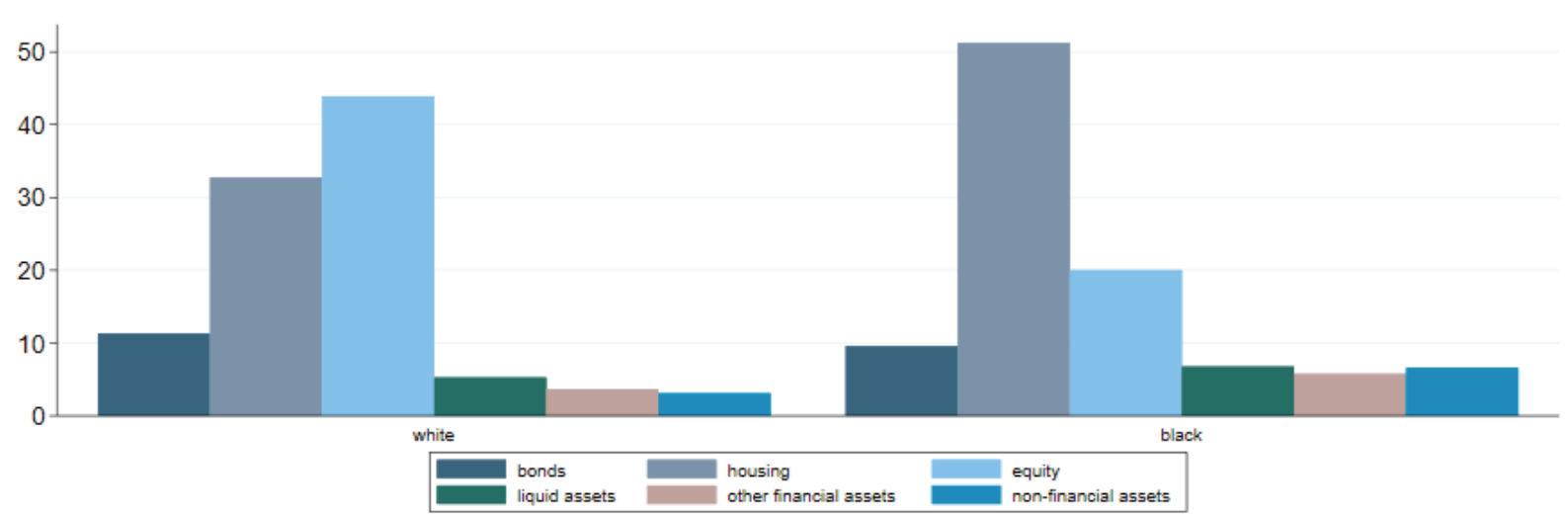

Notes: The graph shows the average portfolio shares of black and white households in percent.

hold wealth to asset price changes. The equity share for white households is much higher, making them much more exposed to the stock market. For black households, we find the housing share to be larger, making them - at least in relative terms - more exposed to the housing market. Still, these relative differences in portfolio composition have to be considered together with absolute wealth levels. For example, Table 1 shows that the little wealth that some black households above the median have is mainly invested in housing. ${ }^{11}$

To illustrate the different sensitivity of black and white portfolios to asset price changes, we consider a 10\% change in the price of each asset and look at how such a shock affects the wealth of black and white households. Figure 5a shows the dollar wealth changes for three major asset classes, bonds, equity, and housing, following a 10\% asset price increase. Changes in asset prices lead to much larger dollar capital gains for white households compared to black households. These differences are not surprising given the large differences in the level of wealth shown in Table 1.

These racial differences in capital gains are only partially mitigated when we look at the wealth gains as a fraction of household income, as shown in Figure 5 b. Even in relation to annual income, we find the differences to still be large; for example, if stock prices rise by 1o percent, then capital gains for white households are over 40 percent of annual income. For black households, the corresponding number is less than 10 percent. These results

\footnotetext{
adjusted with Census X-12 ARIMA.

${ }^{10}$ Liquid assets are the sum of checking accounts, saving accounts, call accounts, money market deposit accounts, prepaid accounts and CDs. Other financial assets include the cash value of life insurance. Non-financial assets are the value of vehicles and other non-financial assets, e.g., jewellery or gold.

${ }^{11}$ These differences are reminiscent of the differences along the wealth distribution documented in Kuhn, Schularick, and Steins (2020).
} 
mean that any capital gain from asset price changes accrue disproportionately to white households.

Figure 5: Capital gains from 10\% increase in asset prices

(a) Per household

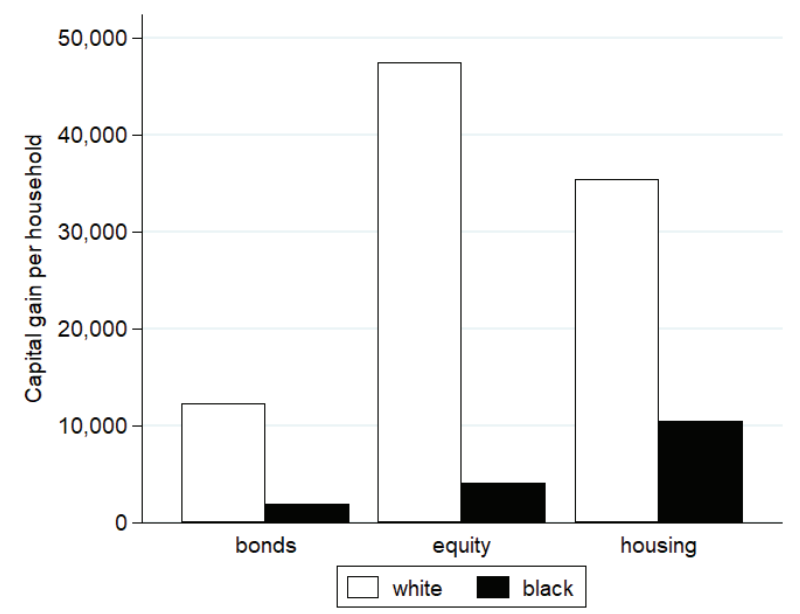

(b) Relative to group income

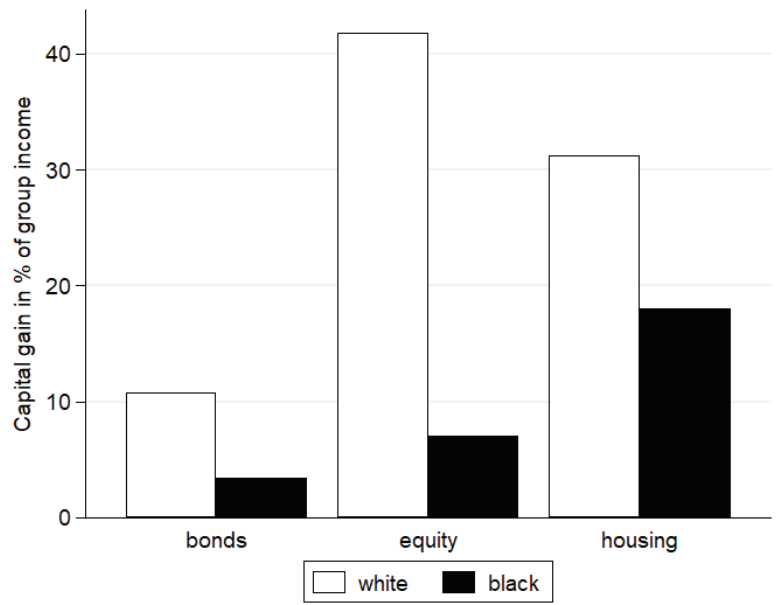

Notes: The left panel shows the capital gains for black and white households from a $10 \%$ increase in the respective asset price per household. The right panel shows the same capital gains as a percentage share of each group's total income.

\subsection{Portfolio composition and interest rate changes}

Black and white households might also be affected differently by changes in debt service and interest income when interest rates change. We consider two ways in which households are affected by lower interest rates after an accommodative monetary policy shock. First, lower interest rates will lead to lower interest income on bank accounts and similar deposittype assets. Unlike for bonds that will increase in value if they have fixed interest rates, the money value of an account balance will not change. What will change are the future income flows from this balance, making a household with a positive balance poorer in expectation. The second way in which households are affected by lower interest rates is if a household is a borrower, in particular if the household borrows on a mortgage contract that allows refinancing at a lower interest rate.

In fact, most U.S. mortgages are fixed-rate mortgages with a built-in call option that provides the borrower the opportunity to prepay. Although refinancing is costly and cumbersome, refinancing activity typically increases when interest rates fall and these lower interest rates will be persistent for the remaining duration of the mortgage (Bhutta and 
Keys, 2016). Refinancing activity is therefore an important example where even transitory changes in interest rates resulting from monetary policy can have long-lasting redistributive effects as households "lock in" the lower interest rate for the remaining maturity of the mortgage. If the mortgage balance is not increased upon refinancing but future interest payments are lowered, then the household is effectively richer. In this sense, households with reduced monthly payments will be richer even if their net worth is unchanged in an accounting sense.

Exploring the interest income and refinancing effects from interest rate changes is, given changing balances and maturities, very complex. To examine the impact of monetarypolicy-induced interest changes on wealth gaps, we will consider a 1oobp fall in interest rates over a one-year horizon. First, we compute the loss in income from lower rates on deposit-type assets for the one-year horizon. This effect is the foregone income from deposit type assets due to the fall in interest rates. Second, to compute the effect from reduced mortgage payments, we assume that all mortgages are refinanced to the lower rate without changing the mortgage balance or remaining time to maturity. The latter effect reflects the change in annual mortgage payments if a household locks in the new lower interest rate by refinancing a fixed-rate mortgage.

Figure 6a shows both the average interest loss on liquid assets after a 1oobp decline in interest rates and similarly the gain from mortgage refinancing. Given the much larger liquid asset holdings of white households shown in Table 1, it ought to be expected that the decline in interest income is much larger for white than for black households. Over one year, the interest income of the average black household goes down by about 100 dollars and it goes down almost six times as much for white households. Expressing these losses relative to income, Figure $6 \mathrm{~b}$ shows that they are small: about $0.5 \%$ of annual income for white households and about half as much for black households. 
Figure 6: Effect of a 1oobp decline in interest rates

(a) Per household

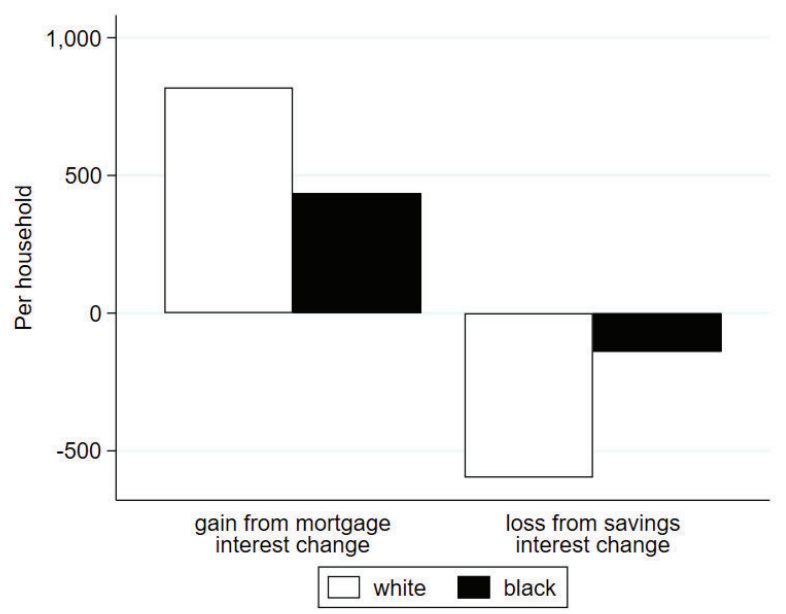

(b) Relative to group income

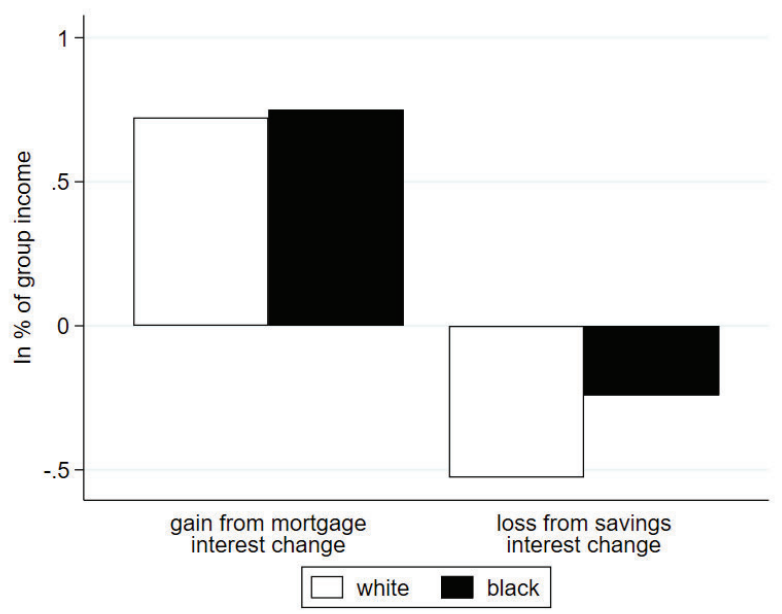

Notes: The left panel shows the average gains for black and white households after a 1oobp decline in mortgage interest rates and their average losses after a 1oobp decline in savings interest rates. The right panel shows the same capital gains as a percentage share of each group's total income.

Mortgage debt balances of U.S. households are, after four decades of growth, large and correspond to almost 100\% of SCF household income (Bartscher et al., 2020). The dollar decline in mortgage payments from refinancing after a 1oobp decrease in interest rates is shown in Figure 6a. We find that the mortgage payments per household decline by 800 dollars for white households and by roughly half as much, 400 dollars, for black households. Figure $6 \mathrm{~b}$ shows that as a fraction of current annual income, the responses are almost equal. For both black and white households, the reduction in mortgage payments corresponds to roughly $0.7 \%$ of annual income. It is important to keep in mind the distribution of homeownership; more than every second black household does not own a house and therefore typically also does not owe mortgage debt.

A decline in interest rates also impacts the interest earnings on bonds, where reinvestments will earn less. This will particularly be the case for mortgage-backed securities, which will mature sooner when lower interest rates increase refinancing. Since bond holdings are only a small part of the average portfolio, we do not show this effect. Moreover, the SCF data show that direct ownership of bonds is concentrated among very wealthy, typically white, households. 


\section{Monetary POlicy, ASSET PRICES AND THE UNEMPloyment GAP}

Section 2 has provided descriptive evidence on heterogeneity in the portfolio composition between black and white households and differences in labor market outcomes, specifically, the racial unemployment gap. We have shown that portfolio heterogeneity between black and white households will lead to very different exposures to asset price changes. To quantify wealth gains from changes in asset prices on the entire portfolio, we combine the comprehensive data on household portfolios from the SCF with estimates of the effects of monetary policy shocks on asset prices. In this section we draw on the literature on monetary policy shocks and develop our estimates of their impact on asset prices and the unemployment gap. We provide estimates of the wealth effects of a policy accommodation for black and white households and compare them to the income effects that result from a closing of the racial unemployment gap.

Our analysis of the impact of monetary policy speaks to a growing policy and theoretical literature concerned with the distributional effects of monetary policy. On the one hand, this debate has been ignited by political concerns about persistent racial inequities. Although distributional questions remain outside central banks' formal mandates, central bankers are increasingly discussing distributional issues. For instance Mary Daly, President of the Federal Reserve Bank of San Francisco, addressed the question: "How can we build a society that delivers on the promise of equal opportunity and inclusive success?" Her answer in part was that "the Fed has a critical role to play" 12 On the other hand, the development of heterogeneous agent models in which monetary policy typically has distributional effects between parts of the population sparked new interest in the size and transmission mechanisms of such effects. Both of these developments suggest that further empirical investigation of the distributional impacts of monetary policy is called for.

\subsection{Monetary policy and asset prices}

Much of the existing literature on the distributional consequences of monetary policy focuses on the income distribution. Coibion et al. (2017) explore the effect of monetary policy shocks on earnings, income, and consumption inequality. They find statistically significant evidence that contractionary monetary policy increases income inequality and provide evidence that consumption rises more for wealthy households than for poor (and

\footnotetext{
${ }^{12}$ https://www.frbsf .org/economic-research/publications/economic-letter/2020/october/isfederal-reserve-contributing-to-economic-inequality-speech/
} 
often minority) households.

Until recently, the effects of monetary policy on the wealth distribution have not attracted much attention for two reasons. First, the asset price effects of monetary policy were considered short-lived so that they do not affect real economic activity and the empirical evidence of these effects was not clear-cut. Recently, a growing body of empirical evidence has however pointed to more persistent effects of monetary policy on asset prices. Market participants have few doubts that monetary policy moves markets, or that monetary policy validates risk-taking and run-ups in asset prices ex-post - the so-called "Fed put" (Authers, 2020; Cieslak and Vissing-Jorgensen, 2020). The growing importance of non-conventional monetary policy that operates through changing the prices of assets in financial markets has also intensified interest in the nexus between monetary policy, risk premia, and asset prices (Bernanke, 2020; Wu and Xia, 2016). For instance, Adam and Tzamourani (2016) use Euro-area data from the Household Finance and Consumption Survey to estimate the impact of asset price changes on the wealth distribution. They observe that the European Central Bank's Outright Monetary Transactions had large effects on asset prices. ${ }^{13}$

There is a growing consensus in the empirical literature that monetary policy affects asset prices over extended periods. Rigobon and Sack (2004) and Bernanke and Kuttner (2005) pioneered empirical approaches. Both studies found substantial effects of policy surprises on stock prices that mainly come from changes in risk premia (excess returns). In both studies, a surprise 1oobp shock lowers stock prices by between $5 \%$ and $7 \%$. Jordà, Schularick, and Taylor (2015) document substantial effects of exogenous changes in monetary conditions on all major asset classes over multi-year horizons in a long-run cross-country data set. A recent paper by Paul (2020) argues that monetary policy today has larger effects on asset prices than in the past. Effects on stock markets that are twice as large as those estimated by Bernanke and Kuttner (2005) are visible over a multi-year horizon. In summary, recent evidence suggests that the effects on asset prices are measurable and persistent over a horizon of many years. ${ }^{14}$

The second reason why the effects of monetary policy on the wealth distribution have only recently come into focus is that few observers were aware of the portfolio heterogeneity between households. Such differences in the composition of portfolios are a necessary

\footnotetext{
${ }^{13}$ Similarly, large effects of quantitative easing on equity prices are shown inHaldane et al. (2016).

${ }^{14}$ Moreover, even over shorter horizons temporary changes in asset prices can have permanent effects if households buy assets at depressed prices Glover et al. (2020) or if capital gains are used to upgrade houses, move to better neighborhoods, or finance education expenditures (Bernanke, 2020). Similarly, interest declines can often be locked in via mortgage refinancing that permanently reduces the burden on debtor households.
} 
condition for asset prices to have distributional effects. Recent work in household finance has exposed these linkages and opened up the possibility that changes in asset prices lead to changes in the wealth distribution. Kuhn, Schularick, and Steins (2020) show that household portfolio composition differs with socioeconomic characteristics, and, as discussed in the previous section, this is also true of black and white households. In particular, in the U.S. the holdings of risky asset such as stocks and corporate bonds are highly concentrated among white households at the top of the wealth distribution. In other words, if monetary policy affects asset prices, it will also affect the black-white wealth distribution because wealth portfolios are systematically different.

A few papers have examined the effect of monetary policy on wealth inequality, starting with Domanski, Scatigna, and Zabai (2016) who use survey data from six major countries and some stylized assumptions about returns in order to explain changes in the wealth distribution during the financial crisis. ${ }^{15}$ Albert and Gómez-Fernández (2018) present a similar exercise with the 2016 Survey of Consumer Finances. They use a structural VAR model to estimate the effect of a high-frequency policy shock (Gertler and Karadi, 2015) on interest rates and house prices. Analyzing Norwegian data, Holm, Paul, and Tischbirek (2020) find evidence that contractionary monetary policy shocks increase income inequality, conforming the findings of Coibion et al. (2017) for the U.S., but that it decreases wealth inequality.

\subsection{Monetary policy and the racial unemployment gap}

Monetary policy accommodation can benefit more economically vulnerable groups with few financial assets through an earnings effect. The idea behind the earnings effect is that expansionary monetary policy reduces unemployment rates and thereby increases the labor income of workers that are marginally attached to the labor market. Such "marginal" workers are disproportionately low-income and minority households, and it is, in particular, the unemployment gap between black and white households that is reduced in reaction to accommodative monetary policy. Such an earnings effect of monetary policy benefiting black households can counteract potential asset price effects that bypass poor households who own few if any financial assets.

Carpenter and Rodgers (2004) explore the effects of contractionary monetary policy on

\footnotetext{
${ }_{15}$ Glover et al. (2020) also emphasize portfolio differences as an important source of redistribution after asset price changes but they do not explore the consequences of monetary policy but of business- cycle-induced changes in asset prices during the Great Recession.
} 
labor market outcomes between black and white workers for the period from 1973-2002 and find a higher sensitivity of black workers' labor market outcomes to monetary policy shocks compared to white workers, with the exception of the labor force participation rate. The positive effects of accommodative monetary policy on low-income and minority employment appear largely uncontroversial, yet the estimated positive effects in labor markets have not yet been contrasted to potential capital gains from asset price changes in financial markets that might be substantially larger. One reason to expect large differences between these asset price and labor market effects is that even large monetary policy shocks as in the aftermath of the financial crisis reduced unemployment rates of black households by only about some tenths of a percentage point.

Carpenter and Rodgers (2004) find that a one-standard-deviation monetary policy shock reduces the black unemployment rate on average by 0.15 percentage points more than the white unemployment rate. The estimated effect is persistent, declines only slightly over time, and remains significant even after four years. Rodgers (2008) explores differential effects of monetary policy on unemployment durations for black and white workers. His evidence is less conclusive but some results point towards a stronger effect on the unemployment duration of black workers than for white workers after contractionary monetary policy shocks. He concludes that "...African Americans disproportionately bear the brunt of disinflationary monetary policy..."(p. 386) .

\subsection{Estimation of the effects of monetary policy}

Our empirical strategy has two parts. In the first step, presented in this section, we will estimate the effects of a monetary policy shock on the price of assets - equities, houses, bonds - and on the black-white unemployment gap in a unified empirical framework which allows for a direct comparison of the resulting income and wealth effects in the second step. Moreover, we will do so using the most commonly used measures for monetary policy shocks to determine a plausible range of the asset price and employment effects.

In a second step, we will calculate how monetary policy differentially affects the wealth and income of black and white households. In other words, we are not estimating the wealth and employment effects directly from the low-frequency micro data. Instead, we use highfrequency macro data to estimate average effects that we apply to "typical" black (white) households from the survey data. The results should be seen as a first-order approximation under the assumption that price effects are equal across asset classes, i.e., black and white households essentially have identical returns on their equity and housing portfolios. 


\subsubsection{Estimation strategy and data}

To study the effects of monetary policy shocks on black (white) employment and wealth, we will use instrumental variable local projections (LP-IV) following Stock and Watson (2018) and Jordà, Schularick, and Taylor (2020). This means we will treat monetary policy shock measures as proxies for the structural shocks in an instrumental variable set-up. The idea here is that surprises and structural shocks are imperfectly correlated. High-frequency surprise measures suffer from measurement error introduced by trading noise and random zero observations in months without FOMC meetings. Instrumenting the current Federal Funds rate (FFR) instead of future rates reduces the problems raised by the potential release of private central bank information discussed by Nakamura and Steinsson (2018). Throughout the analysis, we will scale the policy shocks to represent a 1oobp surprise cut in the current FFR.

Let $\Delta r_{t}$ denote the change in the FFR at time $t$, and let $\Delta z_{t}$ denote the surprise component. We denote as $x$ the vector of controls, which includes 6 lags of the outcome and the shock variable, as well as other predetermined variables such as the unemployment rate, industrial production, and asset prices.

To start with, consider the following set of local projections relating future economic outcomes such as stock and house price changes, as well as the black-white unemployment rate, to changes in interest rates today:

$$
y_{t+h}=\alpha_{h}+\Delta r_{t} \beta_{h}+x_{t} \gamma_{h}+v_{t+h} ; \quad \text { for } h=0, \ldots, H-1,
$$

where $t=1, \ldots, T$.

To obtain exogenous variation in $\Delta r_{t}$, we will turn to proxy measures for structural policy shocks provided by Coibion et al. (2017), Bernanke and Kuttner (2005), Gertler and Karadi (2015). These provide an instrument for the change in the FFR. We will estimate the following set of local projections using instrumental variables (LP-IV):

$$
y_{t+h}=\alpha_{h}+\Delta \widehat{r}_{t} \beta_{h}+x_{t} \gamma_{h}+v_{t+h} ; \quad \text { for } h=0, \ldots, H-1,
$$

which can be compared to the LP-OLS form at (I), and where the estimates of $\Delta \widehat{r}_{t}$ come from the first-stage regression

$$
\Delta r_{t}=x_{t} g+\Delta z_{t} b+\epsilon_{t}
$$


Table 2: Shock series

\begin{tabular}{|c|c|c|}
\hline Name \& Source & Method & Time Period \\
\hline Coibion et al. (2017) & $\begin{array}{l}\text { Extended Romer/Romer shocks identified as } \\
\text { component of policy changes that is orthogonal } \\
\text { to the Fed's information set, Federal Reserve } \\
\text { Greenbook projections for GDP and inflation, } \\
\text { and unemployment }\end{array}$ & $3 / 1969-12 / 2014$ \\
\hline $\begin{array}{l}\text { Bernanke and Kuttner } \\
\text { (2005) }\end{array}$ & $\begin{array}{l}\text { Shocks identified through the difference be- } \\
\text { tween the target rate and the rate implied by } \\
\text { front-month Fed Funds Futures contracts }\end{array}$ & $11 / 1988-11 / 2020$ \\
\hline $\begin{array}{l}\text { Gertler and Karadi } \\
(2015)\end{array}$ & $\begin{array}{l}\text { Shocks identified through a combination of sur- } \\
\text { prise changes to both front-month and 3-month- } \\
\text { forward Fed Funds Futures contracts in a 30- } \\
\text { minute window after FOMC meeting }\end{array}$ & $11 / 1988-6 / 2012$ \\
\hline
\end{tabular}

The control vector $x$ will include contemporaneous values of the variables except the outcome variable (this avoids singularity as we begin at $h=0$ ). The inclusion of contemporaneous variables provides insurance against variation in the policy intervention known to agents at the time of the policy treatment.

Table 2 provides an overview of the three monetary policy shock series that we use in the following analysis. Our benchmark is the widely used shock series by Romer and Romer (2004), extended to 2014 by Coibion et al. (2017) (RR in the following). We also use an extended version of the original shock measure by Bernanke and Kuttner (2005) (BK) that sparked interest in the effect of monetary policy on asset prices. The final shock measure is based on high-frequency price changes in financial markets in a short window around FOMC meetings. We use the series compiled by Gertler and Karadi (2015) (GK). ${ }^{16}$

Data for the prices of financial assets, interest rates and the unemployment rate gap, along with the controls, are all standard macroeconmic time series. Specific variables, definitions and sources are shown in Table 3.

\footnotetext{
${ }^{16}$ The series cover different time periods. We present our results below both using all available data per shock series, and for a common overlapping sample. The differences in the results are minor and we present the estimations with the largest number of observations. We also tested the shocks series by Barakchian and Crowe (2013), and the more recent shocks by Nakamura and Steinsson (2018) and Paul (2020). The results are similar and are available from the authors on request.
} 
Table 3: Economic data

\begin{tabular}{llll}
\hline Variable & Description & Time Period & Source \\
\hline Federal Funds Rate & Federal Funds Target & $11 / 1988-11 / 2020$ & FRB \\
Industrial Production & Industrial Production Index & $1 / 1960-9 / 2017$ & FRB \\
Stock Price & S\&P500 Price & $1 / 1960-9 / 2017$ & S\&P \\
Inflation & CPI, All Urban Consumers & $1 / 1960-9 / 2017$ & BLS \\
House Price & Case-Shiller House Price Index & $1 / 1975-9 / 2017$ & S\&P Corelogic \\
Corporate Debt Yield & Moody's Seasoned Corporate BAA Yield & $1 / 1960-9 / 2017$ & FRB \\
Government Debt Yield & 1o Year Constant Maturity T-Note Yield & $1 / 1960-9 / 2017$ & FRB \\
Unemployment Rate & Seasonally Adjusted Unemployment & $1 / 1960-9 / 2017$ & BLS \\
Black-White Unemployment Gap & Difference in Unemployment & $1 / 1972-9 / 2017$ & BLS \\
\hline
\end{tabular}

\subsubsection{Results}

Figure 7 presents our benchmark estimates for the effect of monetary policy shocks on asset prices and the black-white unemployment gap over a 5-year horizon using the extended RR shock series. We find that stock markets rise by about $5 \%$ in response to the shock and the effect remains sizeable and significant over the entire 5-year horizon. By contrast, the house price response is about half as large in size and falls back to less than $1 \%$ by year 5 . Treasury yields fall on impact, but then return to their original level within a few years. The black-white unemployment gap closes by 0.2 to 0.3 percentage point over the 5 -year period.

In Figure 8, we compare the RR shock response to the other measures for monetary surprises, as discussed above. ${ }^{17}$ As Ramey (2016) points out, different shock measures can lead to different results for individual variables, but in our case the results remain broadly consistent: a $5 \%$ increase in equity prices, and a smaller and more transient increase in house prices of 2-3\%. 10-year Treasury yields drop on impact and remain depressed for some time, before recovering later on.

Importantly, the effect on the unemployment gap is also roughly consistent across the estimations, albeit typically somewhat smaller than in the benchmark RR estimates. In terms of statistical significance, only the RR shocks show a significant response at the 90\% level at all projection horizons. There is clearly some residual uncertainty with respect to the differential employment effects of expansionary monetary policy. Yet, we find that all point estimates show the prominently discussed effect that unemployment rates decline more for black than for white workers so that the unemployment gap closes. What our results also show is that the effects are quantitatively small. After a 1oobp expansionary shock, the unemployment gap closes by at most 20 to $30 \mathrm{bp}$. If these effects translate one-for-one into income effects then they imply that black household incomes increase by

\footnotetext{
${ }^{17}$ Confidence intervals for the estimates with the BK and GK shocks are shown in Appendix AI
} 
$0.2 \%$ relative to white household incomes.

Table 4 shows the complete set of results, including effects on corporate bond yields that we use to gauge the price effects for the corporate bond markets. We find that corporate bond yields fall somewhat more than Treasury yields so that bond spreads compress by about 10 to $15 \mathrm{bp}$, depending on the shock series.

In a recent paper, Paul (2020) proposed a time-varying VAR (TVVAR) to capture different responses of asset prices to monetary policy shocks over time. The idea is that asset prices could exhibit different responses over time, for instance, depending on whether risk appetite in markets is high. We report TVVAR estimates using the Paul (2020) methodology in the Appendix in Table A.I. It is noteworthy that the equity price response is about twice as large in the TVVAR estimation. Against this background, our asset price estimates that remain close to the original estimates by Bernanke and Kuttner (2005) could be a lower bound. By contrast, allowing for a time-varying response of the unemployment gap yields slightly lower and mostly insignificant effects of monetary policy on the unemployment gap between black and white households. The effects peak at 2obp and remain indistinguishable from zero throughout. In this light, our benchmark result on the employment effect could mark an upper bound.

Figure 7: Benchmark estimates using Romer/Romer shocks
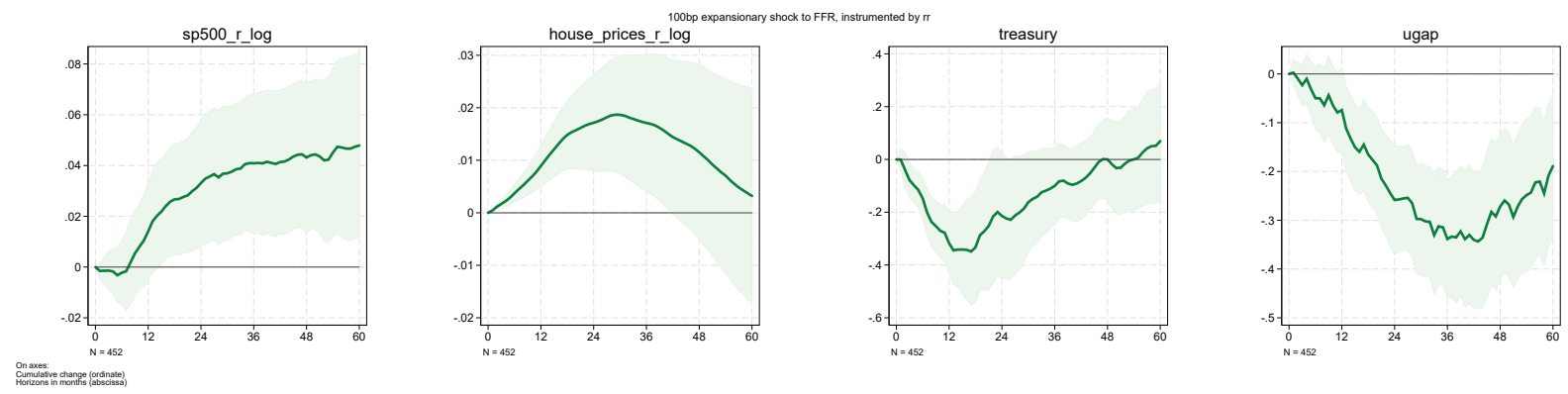

Figure 8: Effects of different monetary policy shocks on asset prices and employment gap: comparing different shock series
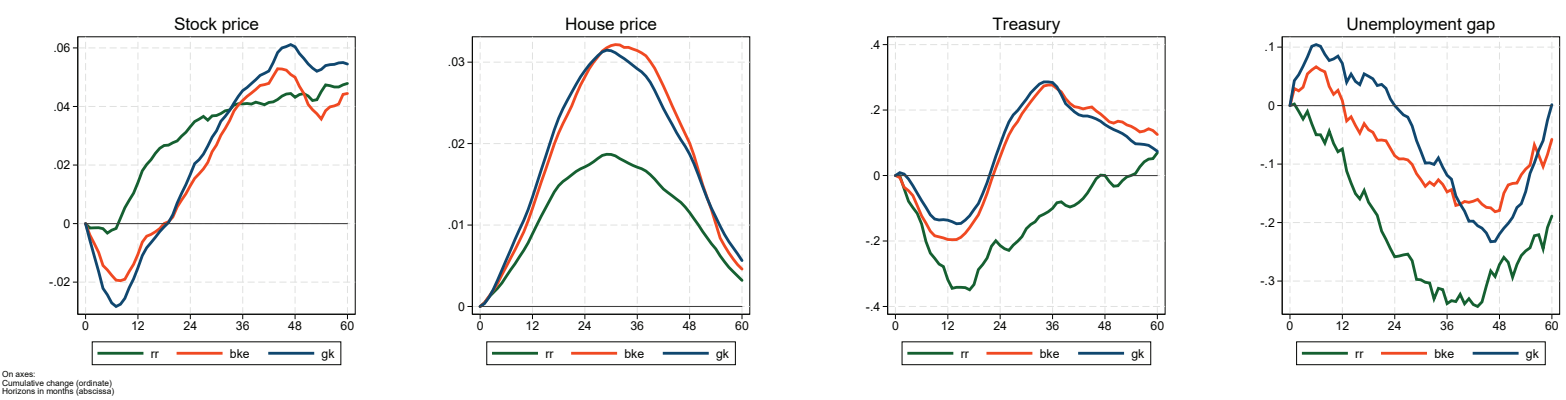
Table 4: LP-IV: full results, 1pp expansionary shock, different shock measures

\begin{tabular}{|c|c|c|c|c|c|c|}
\hline Shock & Horizon & $\begin{array}{l}\text { Stocks } \\
\%\end{array}$ & $\begin{array}{l}\text { Houses } \\
\%\end{array}$ & $\begin{array}{l}\text { Treasury } \\
\text { bp }\end{array}$ & $\begin{array}{l}\text { BAA yield } \\
\text { bp }\end{array}$ & $\begin{array}{l}\text { Unemployment Gap } \\
\text { pp }\end{array}$ \\
\hline \multirow[t]{5}{*}{ Romer / Romer } & $1 Y$ & $\begin{array}{c}0.01 \\
(0.03,-0.01)\end{array}$ & $\begin{array}{c}0.01^{* * *} \\
(0.01,0.01)\end{array}$ & $\begin{array}{c}-0.32^{* * *} \\
(-0.20,-0.43)\end{array}$ & $\begin{array}{c}-0.37^{* * *} \\
(-0.28,-0.46)\end{array}$ & $\begin{array}{c}-0.07 \\
(0.01,-0.16)\end{array}$ \\
\hline & $2 \mathrm{Y}$ & $\begin{array}{c}0.03^{* *} \\
(0.06,0.01)\end{array}$ & $\begin{array}{c}0.02^{* * *} \\
(0.03,0.01)\end{array}$ & $\begin{array}{c}-0.21 \\
(0.02,-0.45)\end{array}$ & $\begin{array}{c}-0.36^{* *} \\
(-0.13,-0.60)\end{array}$ & $\begin{array}{c}-0.26^{* * *} \\
(-0.15,-0.37)\end{array}$ \\
\hline & $3 Y$ & $\begin{array}{c}0.04^{* *} \\
(0.07,0.01)\end{array}$ & $\begin{array}{c}0.02^{* *} \\
(0.03,0.00)\end{array}$ & $\begin{array}{c}-0.10 \\
(0.05,-0.25)\end{array}$ & $\begin{array}{c}-0.23^{* *} \\
(-0.05,-0.42)\end{array}$ & $\begin{array}{c}-0.34^{* * *} \\
(-0.22,-0.46)\end{array}$ \\
\hline & $4 \mathrm{Y}$ & $\begin{array}{c}0.04^{* *} \\
(0.07,0.01)\end{array}$ & $\begin{array}{c}0.01 \\
(0.03,-0.01)\end{array}$ & $\begin{array}{c}0.00 \\
(0.16,-0.16)\end{array}$ & $\begin{array}{c}-0.04 \\
(0.12,-0.21)\end{array}$ & $\begin{array}{c}-0.27^{* * *} \\
(-0.12,-0.42)\end{array}$ \\
\hline & $5 \mathrm{Y}$ & $\begin{array}{c}0.05^{* *} \\
(0.08,0.01)\end{array}$ & $\begin{array}{c}0.00 \\
(0.02,-0.02)\end{array}$ & $\begin{array}{c}0.07 \\
(0.29,-0.15)\end{array}$ & $\begin{array}{c}0.08 \\
(0.29,-0.13)\end{array}$ & $\begin{array}{c}-0.19^{* *} \\
(-0.04,-0.33)\end{array}$ \\
\hline \multirow[t]{5}{*}{ Bernanke / Kuttner } & $1 Y$ & $\begin{array}{c}-0.01 \\
(0.09,-0.11)\end{array}$ & $\begin{array}{c}0.01^{* * *} \\
(0.02,0.01)\end{array}$ & $\begin{array}{c}-0.20 \\
(0.12,-0.51)\end{array}$ & $\begin{array}{c}-0.28 \\
(0.21,-0.78)\end{array}$ & $\begin{array}{c}0.01 \\
(0.37,-0.35)\end{array}$ \\
\hline & $2 \mathrm{Y}$ & $\begin{array}{c}0.01 \\
(0.06,-0.03)\end{array}$ & $\begin{array}{c}0.03 \\
(0.06,0.00)\end{array}$ & $\begin{array}{c}0.06 \\
(0.29,-0.17)\end{array}$ & $\begin{array}{c}-0.25^{* *} \\
(-0.09,-0.41)\end{array}$ & $\begin{array}{c}-0.09 \\
(0.18,-0.35)\end{array}$ \\
\hline & $3 Y$ & $\begin{array}{c}0.04 \\
\text { (0.10,-0.01) }\end{array}$ & $\begin{array}{c}0.03 \\
(0.08,-0.02)\end{array}$ & $\begin{array}{c}0.28 \\
(0.58,-0.03)\end{array}$ & $\begin{array}{c}-0.13 \\
(0.19,-0.45)\end{array}$ & $\begin{array}{c}-0.15 \\
(0.10,-0.39)\end{array}$ \\
\hline & $4 \mathrm{Y}$ & $\begin{array}{c}0.05 \\
(0.13,-0.03)\end{array}$ & $\begin{array}{c}0.02 \\
(0.08,-0.04)\end{array}$ & $\begin{array}{c}0.18 \\
(0.57,-0.22)\end{array}$ & $\begin{array}{c}0.00 \\
(0.21,-0.20)\end{array}$ & $\begin{array}{c}-0.18 \\
(0.49,-0.85)\end{array}$ \\
\hline & $5 \mathrm{Y}$ & $\begin{array}{c}0.04 \\
(0.11,-0.02) \\
\end{array}$ & $\begin{array}{c}0.00 \\
(0.06,-0.05) \\
\end{array}$ & $\begin{array}{c}0.13 \\
(0.63,-0.38)\end{array}$ & $\begin{array}{c}0.21 \\
(0.73,-0.31) \\
\end{array}$ & $\begin{array}{c}-0.06 \\
\text { (o.68,-0.80) }\end{array}$ \\
\hline \multirow[t]{5}{*}{ Gertler / Karadi } & IY & $\begin{array}{c}-0.02 \\
(0.02,-0.05)\end{array}$ & $\begin{array}{c}0.01^{* * *} \\
(0.02,0.01)\end{array}$ & $\begin{array}{c}-0.14 \\
(0.02,-0.30)\end{array}$ & $\begin{array}{c}-0.22^{* * *} \\
(-0.09,-0.34)\end{array}$ & $\begin{array}{c}0.07 \\
(0.22,-0.08)\end{array}$ \\
\hline & $2 \mathrm{Y}$ & $\begin{array}{c}0.02 \\
(0.06,-0.03)\end{array}$ & $\begin{array}{c}0.03^{* * *} \\
(0.04,0.01)\end{array}$ & $\begin{array}{c}0.10 \\
(0.29,-0.10)\end{array}$ & $\begin{array}{c}-0.24^{* *} \\
(-0.08,-0.40)\end{array}$ & $\begin{array}{c}0.00 \\
\text { (0.18,-0.18) }\end{array}$ \\
\hline & $3 Y$ & $\begin{array}{c}0.05 \\
(0.09,0.00)\end{array}$ & $\begin{array}{c}0.03^{*} \\
(0.05,0.00)\end{array}$ & $\begin{array}{c}0.28^{* * *} \\
(0.42,0.15)\end{array}$ & $\begin{array}{c}-0.08 \\
(0.10,-0.26)\end{array}$ & $\begin{array}{c}-0.12 \\
(0.11,-0.34)\end{array}$ \\
\hline & $4 \mathrm{Y}$ & $\begin{array}{c}0.06^{* *} \\
(0.11,0.01)\end{array}$ & $\begin{array}{c}0.02 \\
(0.06,-0.02)\end{array}$ & $\begin{array}{c}0.16 \\
(0.32,-0.01)\end{array}$ & $\begin{array}{c}-0.01 \\
(0.19,-0.20)\end{array}$ & $\begin{array}{c}-0.22^{*} \\
(-0.02,-0.42)\end{array}$ \\
\hline & $5 \mathrm{Y}$ & $\begin{array}{c}0.05 \\
(0.11,0.00)\end{array}$ & $\begin{array}{c}0.01 \\
(0.05,-0.04)\end{array}$ & $\begin{array}{c}0.07 \\
(0.22,-0.07)\end{array}$ & $\begin{array}{c}0.14 \\
(0.35,-0.06)\end{array}$ & $\begin{array}{c}0.00 \\
(0.23,-0.22)\end{array}$ \\
\hline
\end{tabular}

Notes: Confidence intervals in brackets reported at 90\%. The number of observations for the estimations using RR shocks is 452 ; for BK shocks 287 ; for GK shocks 284 .

Summing up, the empirical results show a substantial asset price boosting effect of surprise monetary easing, in combination with a reduction in the black-white unemployment gap. If white households profit disproportionately from such asset price increases, then the observed effects open up the possibility that the portfolio effects of monetary easing go in the opposite direction of the income effects. 


\section{EARNINGS AND PORTFOLIO EFFECTS OF MONETARY POLICY}

More accommodative monetary policy benefits black households by decreasing their unemployment rate and increasing their earnings. But the same policies widen racial wealth differences, as white household portfolios benefit more than those of black households from asset price changes induced by monetary policy surprises. In this section, we first calculate the effects of a monetary policy shock on the wealth of the average black and white household. Since the wealth distribution is highly skewed, we next examine the portfolio effects along the wealth distribution. Finally, we calculate the effect of a monetary policy shock on the gap between black and white earnings and compare the size of the portfolio and earnings effects over different horizons.

\subsection{Effects on household wealth}

In the previous section, we estimated the effects of monetary policy shocks on asset prices and interest rates. A last step is needed before we can estimate the impact of a monetary policy shock on wealth. For financial assets, we need to transform the effect on interest rates into a change in the asset price using an assumption about duration. We use duration estimates from Bloomberg for the average duration of outstanding 10-year Treasuries (7.07), mortgage-backed securities (5.47), and corporate bonds (5.43) and apply them to the corresponding asset categories in the SCF data. ${ }^{18}$ To be consistent with stock and house price changes, which are real, the nominal change in each bond wealth category is deflated using the estimated responses of inflation to the policy shock.

Based on these assumptions, we are in a position to estimate the effects of the monetary policy shock (a 1oobp surprise decline in the funds rate) on asset prices. The asset price responses are shown in Figure 9 with the RR policy shocks (Figure 9a), the BK shocks (Figure 9b), and the GK shocks (Figure 9c). In all cases, the total gains in wealth to white households are much larger than the gains to black households.

An unanticipated monetary policy accommodation leads to asset price changes that benefit white households to a much larger extent than black households because average white wealth is much larger and a larger fraction is held in equities. White households experience more capital gains from monetary policy shocks and the changes in policy serve to

\footnotetext{
${ }^{18}$ We use corporate duration and yield for corporate and foreign bonds, the treasury duration and yield for government and state and municipal bonds, and the MBS duration and corporate yield for mortgage-backed bonds.
} 
exacerbate the black-white wealth gap.

There are small differences in the size and persistence of the responses depending on the shock series used to estimate price and interest rate effects. The results with RR shocks are somewhat smaller than with BK or GK shocks, although the effects are more persistent with RR shocks. With the RR policy shock, the largest effects are after three years, reaching about $\$ 25,000$ for white households and about one-fifth as much for black households. The effects are largest with the GK shocks, with a peak after four years of about $\$ 35,000$ for white households and about $\$ 5$, ooo for black households. With all shock series, the biggest effect comes from the large and persistent effect of equity prices. The house price influence is larger with the GK estimates, although it diminishes over time with both sets of shock estimates. Bond effects are small because bond holdings are only a small fraction of total wealth for both black and white households.

Figure 9: Total effects over time by shock type, per household

(a) RR shock

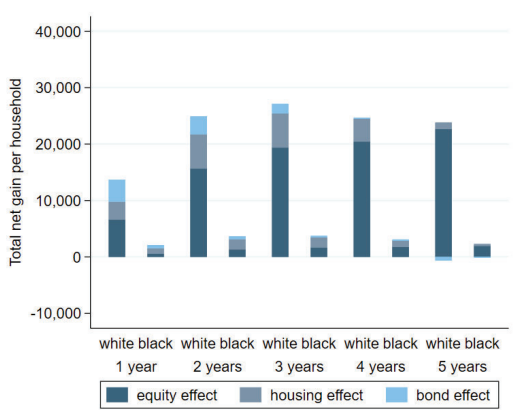

(b) BK shock

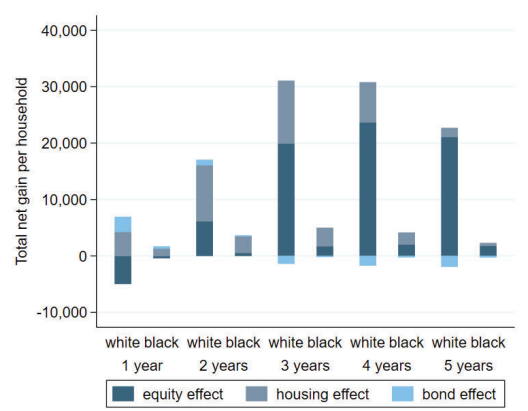

(c) GK shock

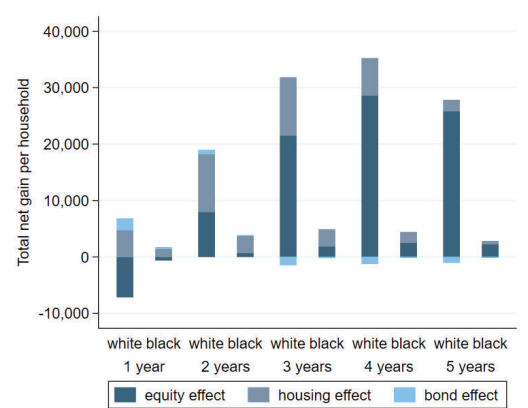

Notes: The figure shows the average wealth effects for black and white households after a 1oobp monetary shock (RR, BK and GK shocks) over time.

In addition to the portfolio effects, i.e., the direct effects of capital gains from the monetary shock, there are potentially additional indirect effects of monetary policy shocks if accommodative monetary shock reduces mortgage interest rates and the interest earned on deposit-type assets. We estimate these effects using the methodology described in Section 2.4. We assume that the impact of the 1oobp accommodative monetary shock on mortgage rates is given by the impacts on the 10-year Treasury rate shown in Table 4 and use the impact at a 1-year horizon to calculate the savings on monthly mortgage payments, which are annualized to give an approximation of the implicit increase in wealth that occurs when mortgages are refinanced at a lower rate. For liquid assets held by the household, we assume that the decline in interest earnings is the same size as the monetary policy shock, Ioobp. In this case, the response is identical to the one in Figure 6a in Section 2.4. 
In Figure 10, we show the mortgage interest and deposit rate effects from the monetary shock, using the RR shocks, BK shocks and GK shocks. Interestingly, black households, with small deposit balances to begin with, lose little from lower interest rates; the average black household gains more from mortgage refinancing. White household deposit interest losses, almost 6oo dollars, are higher than the average gains from refinancing, but only by about 200 dollars. The gains from refinancing are somewhat smaller with the GK shocks and we find differences between the gains from refinancing to black and white households to be not dramatic.

Figure 10: Effects of monetary policy shocks on mortgage refinancing and savings interest, per household

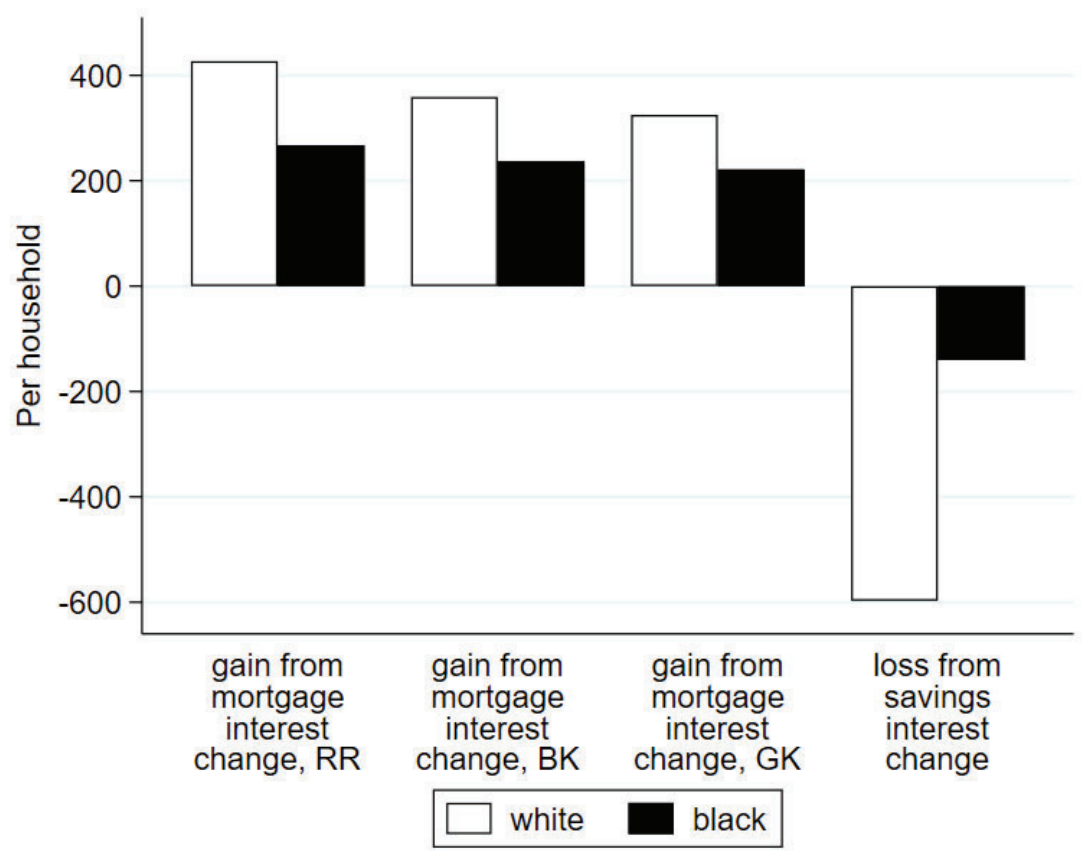

Notes: The graph shows the average gains for black and white households after a decline in mortgage interest rates as implied by the RR, BK and GK shocks, and their average losses after a 1oobp decline in savings interest rates.

\subsection{Portfolio effects along the wealth distribution}

Our previous estimates of the effects of asset price changes on the wealth of black and white households considered the average black and white household. However, (Kuhn and Ríos-Rull, 2016) show that the U.S. wealth distribution is highly skewed. Table 1 demonstrates that there are large differences between the mean and the median for both black and white households in our data. Mean holdings are much larger than median 
holdings. Moreover, less than half of all black households hold some types of assets, so the median is zero. For example, only 35 percent of black households own stocks, and 46 percent own a home. In this section, we examine whether the skewness of the wealth distribution affects our conclusions regarding the effect of a monetary policy shock on the wealth gap.

Figure 11: Lorenz curve of portfolio gains

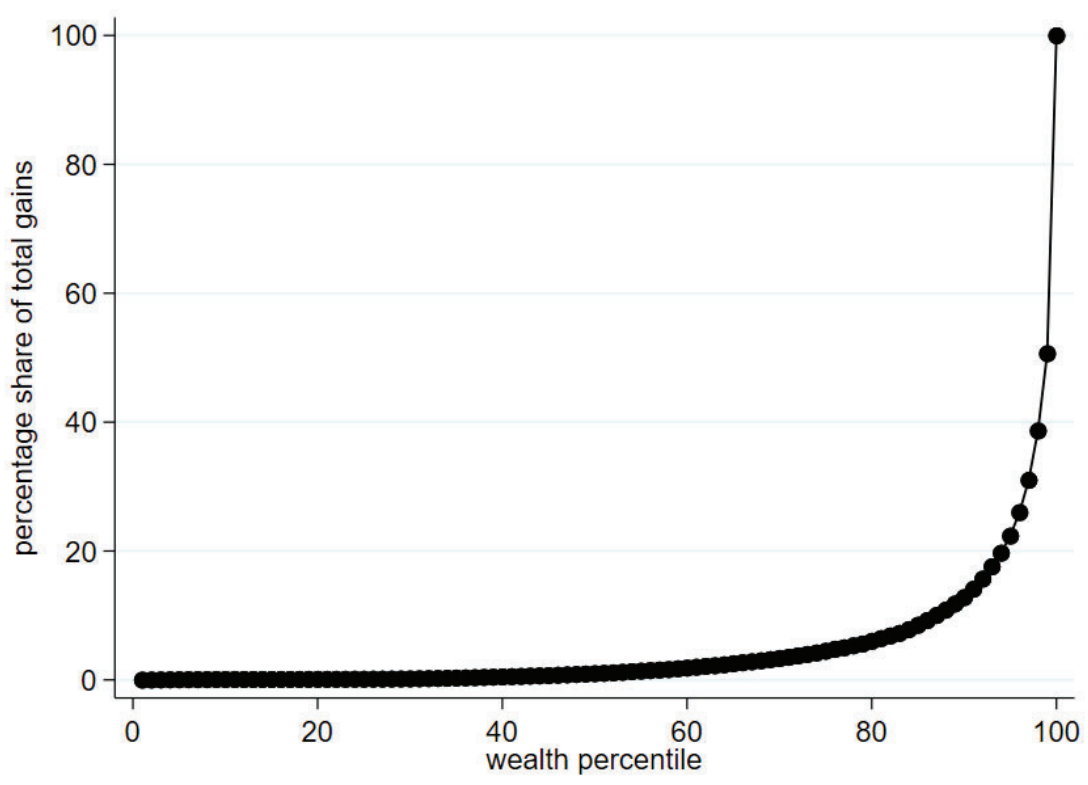

Notes: The graph shows the Lorenz curve of the total portfolio effect along the wealth distribution five years after the shock.

We will consider a 100 bp monetary policy surprise and use the same methodology as before to estimate the effects on asset prices, interest rates and hence wealth. The distributional implications of the portfolio effects are shown in Figure 11, where we show the impact of a monetary policy surprise after five years based on our benchmark RR shocks. The figure presents a Lorenz curve of the wealth gains along the distribution of wealth for all households. It shows a highly unequal distribution of the gains from an expansionary monetary policy shock. About 80 percent of all gains accrue to households in the top 5 percent of the wealth distribution and about 50 percent go to the top 1 percent. Notably, this distribution is substantially more unequal than the distribution of wealth itself. The facts that (a) equity gains account for a large share of the total gains and (b) equity holdings are highly concentrated along the wealth distribution lead to a high concentration of the gains from monetary policy in the - mainly white - top to percent of the wealth distribution. ${ }^{19}$

${ }^{19}$ The black households in our data are very unequally distributed along the wealth distribution. Among 
Since portfolio gains are so highly concentrated among wealthy households, it is reasonable to suspect that the wealth gap among more "typical" households is less affected by asset price changes. In order to examine this, we will look at black and white households around the median, which we define as households between the 4oth and 6oth percentiles of their respective wealth distributions.

Figure 12: Portfolio effects for black and white households around the median

(a) $R R$ shock

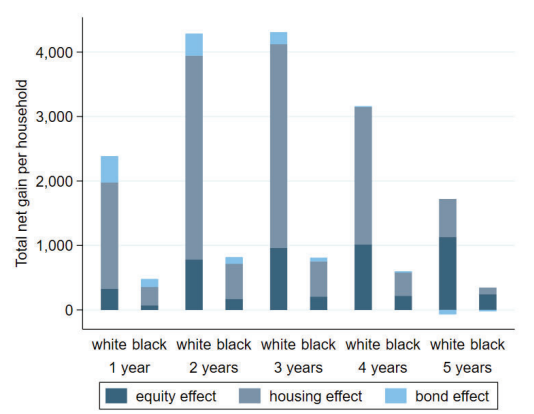

(b) BK shock

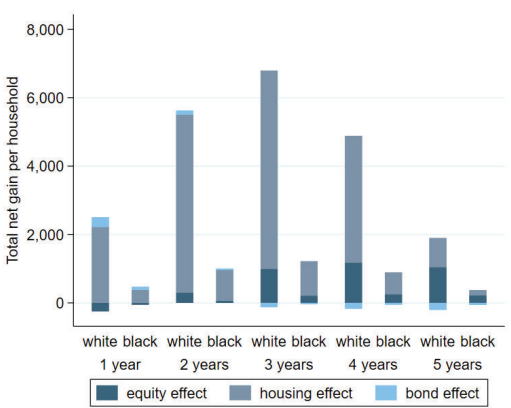

(c) GK shock

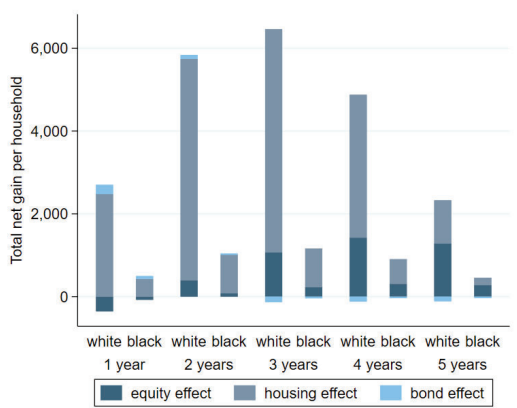

Notes: The figure shows the average wealth effects for black and white households around the median after a Ioobp monetary shock over time. The panels show results based on the impact of RR, BK and GK shocks, respectively. The underlying portfolios are constructed by averaging across all households between the 4oth and 6oth percentile of the respective wealth distributions separately for black and white households.

The portfolio effects of a monetary policy surprise on black and white households around the median are shown in Figure 12. Comparing the effects around the median to the average effects in Figures ga to 9c, we find that gains are smaller in levels but that the relative differences between black and white households persist. We still find that the gains of white households are more than four times larger than the gains of black households. The gains around the median differ in their composition relative to the mean effects because of the differences in the portfolio composition along the wealth distribution. We find that around the median, most of the gains stem from housing, whereas equity gains are the largest part at the mean. The fact that housing plays a more dominant role around the median than at the mean also makes the gains slightly less persistent. Still, we find that the gains are almost the same size in year 5 as in year 1 .

In Table 1, we reported that a large share of black households do not own any assets of several types and if they do, their holdings are often small. To see the implications of this, we look at the shares of black and white households who have portfolio gains that are less than one percent of their annual income 5 years after an expansionary 100 bp shock. We

the bottom 50 percent of households, the share of black households is 24 percent. Their share is 9 percent among households between the 5oth and goth percentile. Only 2 percent of households among the top 10 percent wealthiest households are black. 
Figure 13: Effects of monetary policy shocks on mortgage refinancing and savings interest for black and white households around the median

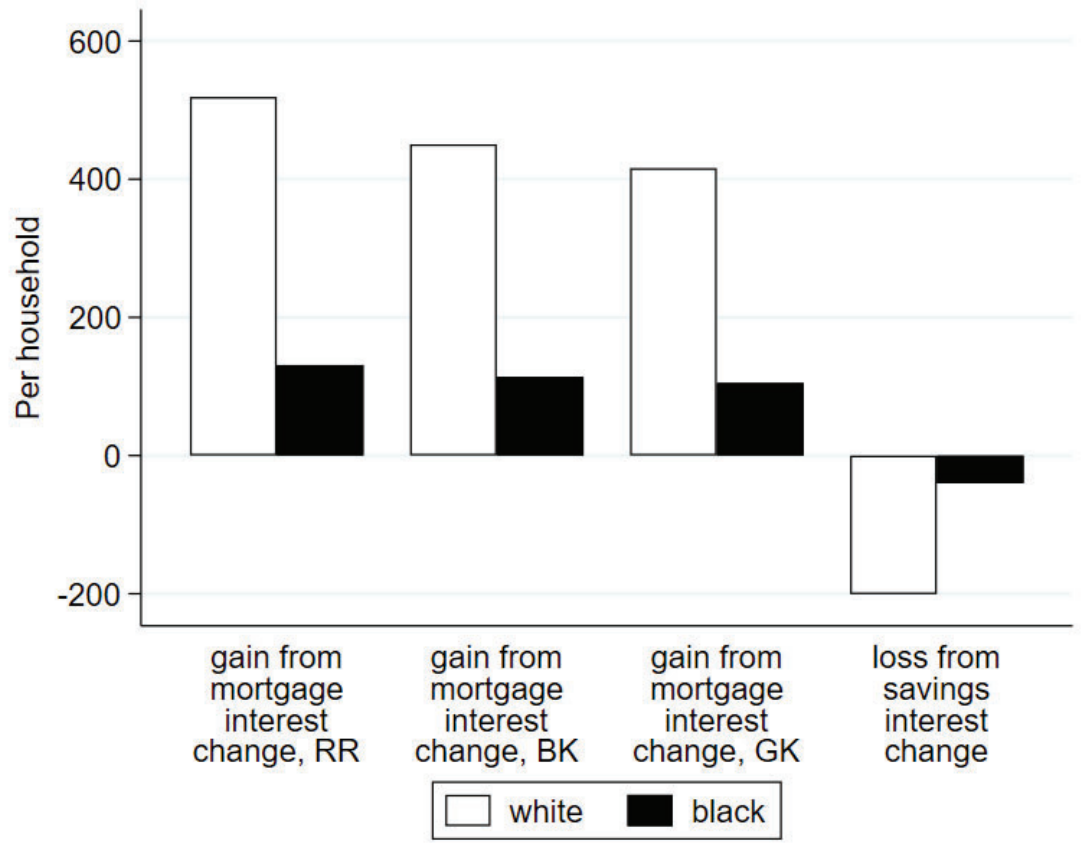

Notes: The graph shows the average gains for black and white households around the median after a decline in mortgage interest rates as implied by the RR, BK and GK shocks, and their average losses after a 1oobp decline in savings interest rates. The underlying portfolios are constructed by averaging across all households between the 4oth and 6oth percentile of the respective wealth distributions for black and white households.

again consider estimates that use our baseline with the RR shocks, and refer to households with a portfolio gain below one percent of income as having no portfolio effect. We find that about one third of white households ( 36 percent) fall in the group of households with no portfolio effect after 5 years. By contrast, the share among black households is about twice as large (65 percent). Hence, almost two out of three black households are left with no portfolio gains 5 years after an expansionary monetary policy shock. ${ }^{20}$

In Figure 13, we show the effects of monetary policy shocks on mortgage refinancing and interest on saving for black and white households around the median, using the same assumptions as in the results for the mean households in Figure 10. White households around the median have gains from mortgage refinancing which are about four times larger than the gains for black households, a much larger difference than for the mean household because many more of the black households around the median do not own a home.

\footnotetext{
${ }^{20}$ If we consider a 5-percent threshold instead of the 1-percent threshold, the shares increase to 69 percent for white households and 91 percent for black households.
} 


\subsection{Quantifying the earnings effect}

Our estimates indicate that an accommodative monetary policy shock benefits black households since it reduces their unemployment rates more than for white households. In this section, we aim to quantify the earnings effects from reduced unemployment rates. We combine the low-frequency 2019 SCF data on labor income with our estimates of the impact of monetary policy shocks on the unemployment gap. Using this estimate, we will be in a position to compare the relative gains from the earnings and wealth effects for black and white households.

For our calculation, we focus on prime-age household heads (age 25-55) and on the information if the head has been unemployed during the 12 months before the interview. ${ }^{21}$ There are large differences in the unemployment experiences of black and white households. The share of black household heads experiencing unemployment in the year prior to the interview is 12.4 percent, while the share for white household heads is 8.3 percent. Comparing earnings of households who have been and who have not been unemployed during the past 12 months, we find that average earnings of black households whose head has not been unemployed are $\$ 56,200$. For households whose head experienced unemployment within the last 12 months, the average annual labor income is $\$ 27,500 .{ }^{22}$ By contrast, we find that white households who experienced unemployment during the last 12 months still report average earnings of $\$ 50,300$ - almost the level of black households without unemployment experience. White households without unemployment experience over the last 12 months report on average labor income of more than \$103,000 in the 2019 SCF data.

To derive the earnings effect, we start with the estimated impact of an accommodative monetary policy shock on the unemployment gap between black and white households shown in Table 4 and then make a number of conservative assumptions in order to relate the change in the unemployment gap to earnings changes. Specifically, we assume that each black household who finds employment receives the average earnings of employed black households. Hence, we assume that the reduction in unemployment corresponds to an equally large increase in labor income. Again, this implies a conservative assumption for constructing the earnings effect of an expansionary monetary policy because we arguably assume an upper bound on the earnings change by assuming that all additionally employed

\footnotetext{
${ }^{21}$ We consider the last 12 months rather than the current labor force status at the interview because the surveyed labor income also refers to the previous calendar year.

${ }^{22}$ Sample sizes are small: we observe 182 white households and 64 black households whose head reports unemployment during the last 12 months.
} 
black households will earn the average labor earnings of employed black households.

For our estimate of the increase in black earnings we multiply the difference in earnings between black households that have and have not experienced unemployment from the 2019 SCF by our estimates of the impact of monetary policy on the differential between black and white unemployment rates. Once more, we use the conservative assumption that white households who find employment enjoy the same average earnings gain as black households, namely $56,200-27,500=28,700$ dollars. The additional income gain of black households is computed by multiplying the estimated impact of the monetary policy shock on the unemployment gap with the average earnings gain of $\$ 28,700$.

More formally, let us denote the estimated effect on the unemployment gap at projection horizon $h$ by $\Delta_{h} u$ and the earnings gain from leaving unemployment for black households by $\Delta Y^{B}=Y_{E}^{B}-Y_{U}^{B}$ where $Y_{E}^{B}$ denotes average labor income of black households who have note been unemployed over the past 12 months and $Y_{U}^{B}$ denotes labor income of black households who have been unemployed at least for some time in the past year. In the 2019 SCF data, we find $\Delta Y^{B}=\$ 28,700$. Our estimate for the relative earnings gain for black households relative to white households in period $h$ after the monetary policy shock, $\Delta_{h} Y$, can then be expressed as

$$
\Delta_{h} Y=\Delta_{h} u \Delta Y^{B}=\Delta_{h} u\left(Y_{E}^{B}-Y_{U}^{B}\right)
$$

The largest effect on the unemployment gap in Table 4 is estimated with the RR shock series. The effect peaks in year 3 when the unemployment rate gap is reduced by 0.34 percentage points. The relative earnings gain is found my multiplying that gap reduction and the average earnings gain which yields a gain per black household of \$97.6, or 0.19 percent of annual total income for all black households.

\subsection{Comparing earnings and portfolio effects}

The estimated earnings effect $\Delta_{h} Y$ is the impact of the monetary policy shock on the difference in earnings between black and white households. Thus, the appropriate comparison to the portfolio effect is the difference in capital gains accruing to black and white households. Continuing with the above example, where we found $\Delta_{3} Y=\$ 97.60$ or 0.19 percent of annual income, the corresponding portfolio effect after three years estimated with the RR shock series shock is about 24 percent of annual income for white households and 6.5 
percent for black households. The differential gain of white households relative to black households is 17.5 percent. This comparison suggests that the portfolio effect for white households is substantially larger than the earnings effect for black households that we already constructed as a conservative upper bound. Put differently, the 17.5 percent differential capital gain of white households as fraction of income is two orders of magnitude larger than the earnings effect of 0.19 percent.

Figure 14: Comparison of earnings and portfolio effects

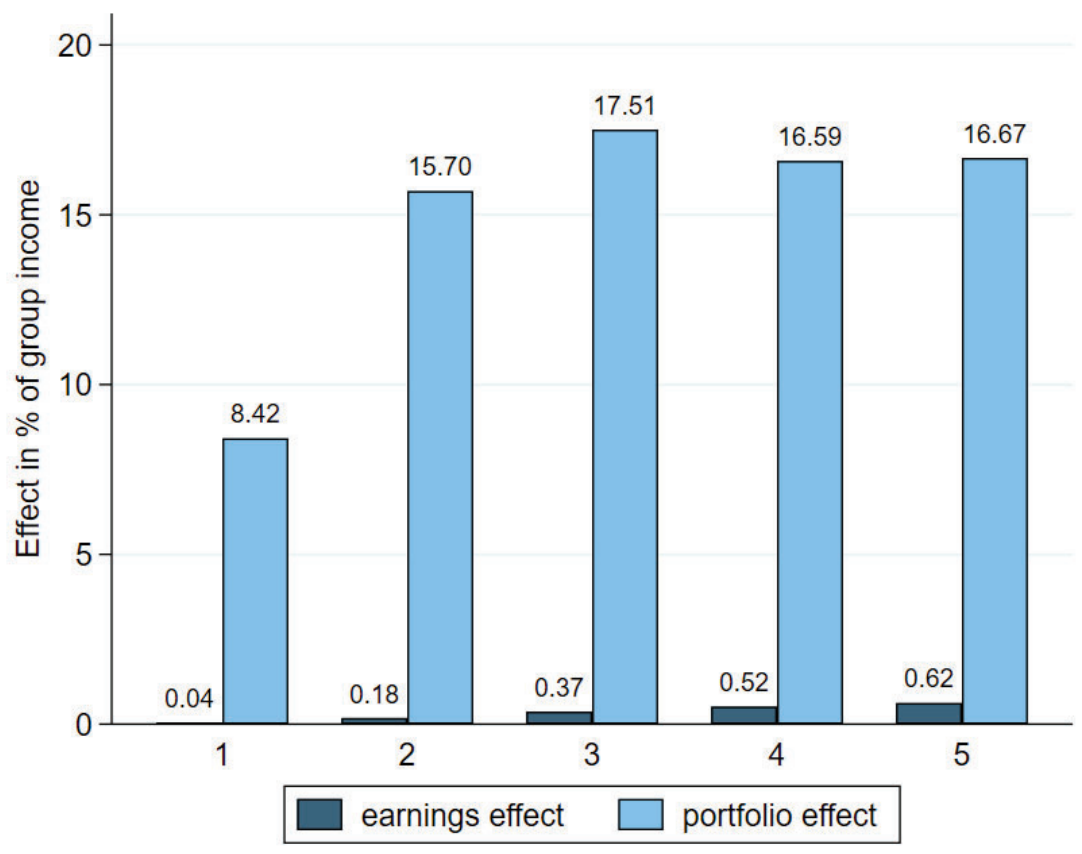

Notes: The graph compares the cumulated earnings effect to the portfolio effect based on the RR shocks.

However, there is an important conceptual difference between the two effects. The earnings effect applies to the flow of earnings while the capital gains are a gain on the stock of wealth. Thus, the capital gain is a one-time change in the valuation of assets while the earnings effect applies to incomes also in subsequent years. To take this difference into account, we compare the difference in capital gains between white and black households over the five-year horizon to the accumulated estimate of the (differential) earnings effect over this time period.

Figure 14 shows the year-by-year accumulated earnings effects and the difference in the portfolio effects on black and white households from a monetary policy shock. Note that for easier comparison, we construct the differences to be always positive; capital gains are larger for white households and earnings gains are larger for black households. The 
estimates shown use our baseline, the RR shock series, to estimate the impact of monetary policy on asset prices, interest rates and the unemployment gap. Estimates with the BK or GK shocks are very similar.

Even as the earnings effect accumulates over time, it remains orders of magnitude smaller than the the effects from capital gains. We find support for the idea that expansionary monetary policy improves the labor market situation of black households more than for white households. Yet, when we contrast these effects to the gains from asset price changes, the earnings gains of black households are dwarfed by the portfolio gains of white households. We conclude that even a large and persistent earnings effect does not equalize the inequality-increasing consequences of expansionary monetary policy on household wealth.

\section{Conclusion}

We have shown that policy shocks that change asset prices have differential effects on the wealth of black and white households. White households gain more because they have more financial wealth and hold portfolios that are more concentrated in interest-rate sensitive assets such as equities. At the same time, monetary policy shocks reduce the gap between black and white unemployment rates and bring larger earnings gains for black households. Bringing the two together, however, leads to one stark finding: the reduction in the earnings gap pales in comparison to the effects on the wealth gap.

Our analysis therefore does not bode well for the suggestion made by politicians and central bankers that a more accommodative monetary policy helps alleviate racial inequalities. With the instruments available - all of which work through effects on asset prices and interest rates - a central bank would not be able to design policies for an income gap reduction objective without increasing wealth inequality. Clearly, this does not mean that achieving racial equity should not be a first-order objective for economic policy. We strongly think it should. But the tools available to central banks might not be the right ones, and could possibly be counter-productive. 


\section{REFERENCES}

Adam, Klaus and Panagiota Tzamourani (2016). "Distributional Consequences of Asset Price Inflation in the Euro Area." In: European Economic Review 89, pp. 172-192.

Albert, Juan-Francisco and Nerea Gómez-Fernández (2018). Monetary Policy and the Redistribution of Net Worth in the US. Working Paper.

Aliprantis, Dionissi and Daniel R. Carroll (2019). What Is Behind the Persistence of the Racial Wealth Gap? Working Paper February. URL: https://ideas.repec.org/a/fip/fedcec/ $00095 . \mathrm{html}$.

Auclert, Adrien (2019). "Monetary policy and the redistribution channel." In: American Economic Review 109.6, pp. 2333-67.

Auclert, Adrien, Matthew Rognlie, and Ludwig Straub (2020). Micro jumps, macro humps: Monetary policy and business cycles in an estimated HANK model. Working Paper. National Bureau of Economic Research.

Authers, John (2020). The Fed's Stocks Policy Is Exuberantly Asymmetric, 2020. Working Paper. URL: https : //www . bloomberg . com/opinion/articles/2020-08-04/fed-props-upfalling-stocks-doesn-t-try-to-prick-bubbles.

Bartscher, Alina K, Moritz Kuhn, Moritz Schularick, and Ulrike Steins (2020). Modigliani Meets Minsky: Inequality, Debt, and Financial Fragility in America, 1950-2016. Working Paper.

Bayer, Christian, Ralph Lütticke, Lien Pham-Dao, and Volker Tjaden (2019). "Precautionary savings, illiquid assets, and the aggregate consequences of shocks to household income risk." In: Econometrica 87.1, pp. 255-290.

Bernanke, Ben S. (2020). "The New Tools of Monetary Policy." In: American Economic Review 110.4, pp. $943-83$.

Bernanke, Ben S. and Kenneth N. Kuttner (2005). "What Explains the Stock Market's Reaction to Federal Reserve Policy?" In: The Journal of finance 60.3, pp. 1221-1257.

Bhutta, Neil, Jesse Bricker, Andrew C. Chang, Lisa J. Dettling, Sarena Goodman, Joanne W. Hsu, Kevin B. Moore, Sarah Reber, Alice Henriques Volz, and Richard Windle (2020). "Changes in US Family Finances from 2016 to 2019: Evidence from the Survey of Consumer Finances." In: Federal Reserve Bulletin 106.5.

Bhutta, Neil and Benjamin J. Keys (2016). "Interest Rates and Equity Extraction during the Housing Boom." In: American Economic Review 106.7, pp. 1742-74.

Bricker, Jesse, Lisa J. Dettling, Alice Henriques, Joanne W. Hsu, Lindsay Jacobs, Kevin B. Moore, Sarah Pack, John Sabelhaus, Jeffrey Thompson, and Richard A. Windle (2017). 
"Changes in US Family Finances from 2013 to 2016: Evidence from the Survey of Consumer Finances." In: Federal Reserve Bulletin 103, p. 1.

Bricker, Jesse, Alice Henriques, Jacob Krimmel, and John Sabelhaus (2016). "Measuring Income and Wealth at the Top Using Administrative and Survey Data." In: Brookings Papers on Economic Activity 2016.1, pp. 261-331.

Carpenter, Seth B. and William M. Rodgers (2004). "The Disparate Labor Market Impacts of Monetary Policy." In: Journal of Policy Analysis and Management 23.4, pp. 813-830.

Chetty, Raj, Nathaniel Hendren, Maggie R. Jones, and Sonya R Porter (2020). "Race and economic opportunity in the United States: An intergenerational perspective." In: The Quarterly Journal of Economics 135.2, pp. 711-783.

Cieslak, Anna and Annette Vissing-Jorgensen (2020). The economics of the Fed put. Working Paper. National Bureau of Economic Research.

Coibion, Olivier, Yuriy Gorodnichenko, Lorenz Kueng, and John Silvia (2017). "Innocent Bystanders? Monetary policy and inequality." In: Journal of Monetary Economics 88, pp. 7089. URL: http://wWw.sciencedirect.com/science/article/pii/S0304393217300466.

Domanski, Dietrich, Michela Scatigna, and Anna Zabai (2016). "Wealth Inequality and Monetary Policy." In: BIS Quarterly Review March.

Emmons, William (2020). Housing Wealth Climbs for Hispanics and Blacks, Yet Racial Wealth Gaps Persist, Federal Reserve Bank of St. Louis, April 1, 2020. Working Paper.

Gertler, Mark and Peter Karadi (2015). "Monetary Policy Surprises, Credit Costs, and Economic Activity." In: American Economic Journal: Macroeconomics 7.1, pp. 44-76.

Glover, Andrew, Jonathan Heathcote, Dirk Krueger, and José-Víctor Ríos-Rull (2020). "Intergenerational Redistribution in the Great Recession." In: Journal of Political Economy 128.10, pp. 3730-3778.

Gornemann, Nils, Keith Kuester, and Makoto Nakajima (2016). "Doves for the rich, hawks for the poor? Distributional consequences of monetary policy." In:

Haldane, Andrew, Matt Roberts-Sklar, Chris Young, and Tomasz Wieladek (2016). "QE: the story so far." In:

Holm, Martin, Pascal Paul, and Andreas Tischbirek (Jan. 2020). The Transmission of Monetary Policy under the Microscope. Working Paper Series 2020-03. Federal Reserve Bank of San Francisco. URL: https://ideas.repec.org/p/fip/fedfwp/87419.html.

Jordà, Òscar, Moritz Schularick, and Alan M Taylor (2015). "Leveraged Bubbles." In: Journal of Monetary Economics 76, S1-S20. 
Jordà, Òscar, Moritz Schularick, and Alan M. Taylor (2020). “The Effects of Quasi-Random Monetary Experiments." In: Journal of Monetary Economics 112, pp. 22-40.

Kaplan, Greg, Benjamin Moll, and Giovanni L. Violante (2018). “Monetary policy according to HANK." In: American Economic Review 108.3, pp. 697-743.

Kekre, Rohan and Moritz Lenel (2020). "Monetary policy, redistribution, and risk premia." In: University of Chicago, Becker Friedman Institute for Economics Working Paper 2020-02.

Kuhn, Moritz and José-Víctor Ríos-Rull (2016). “2013 Update on the US Earnings, Income, and Wealth Distributional Facts: A View from Macroeconomics." In: Federal Reserve Bank of Minneapolis Quarterly Review 37.1, pp. 2-73.

Kuhn, Moritz, Moritz Schularick, and Ulrike I. Steins (2020). "Income and Wealth Inequality in America, 1949-2016." In: Journal of Political Economy 128.9, pp. 3469-3519. URL: https://ideas.repec.org/a/ucp/jpolec/doi10.1086-708815.html.

Luetticke, Ralph (2018). "Transmission of monetary policy with heterogeneity in household portfolios." In:

Nakamura, Emi and Jón Steinsson (2018). "Identification in macroeconomics." In: Journal of Economic Perspectives 32.3, pp. 59-86.

Paul, Pascal (2020). "The Time-varying Effect of Monetary Policy on Asset Prices." In: Review of Economics and Statistics 102.4, pp. 690-704.

Ramey, Valerie A. (2016). "Macroeconomic shocks and their propagation." In: 2, pp. 71-162.

Rigobon, Roberto and Brian Sack (2004). "The Impact of Monetary Policy on Asset Prices." In: Journal of Monetary Economics 51.8, pp. 1553-1575.

Rodgers, William M. (2008). "African American and White Differences in the Impacts of Monetary Policy on the Duration of Unemployment." In: American Economic Review 98.2, pp. 382-86.

Romer, Christina D. and David H. Romer (2004). "A new measure of monetary shocks: Derivation and implications." In: American Economic Review 94.4, pp. 1055-1084.

Stock, James H. and Mark W. Watson (2018). "Identification and estimation of dynamic causal effects in macroeconomics using external instruments." In: The Economic Journal 128.610, pp. 917-948.

Wolff, Edward N. (2016). "Household Wealth Trends in the United States, 1962 to 2013: What Happened Over the Great Recession?" In: RSF: The Russell Sage Foundation Journal of the Social Sciences 2.6, pp. 24-43. 
Wu, Jing Cynthia and Fan Dora Xia (2016). "Measuring the Macroeconomic Impact of Monetary Policy at the Zero Lower Bound." In: Journal of Money, Credit and Banking 48.2-3, pp. 253-291. 


\section{A. Appendix}

\section{A.1. Impulse responses and confidence intervals with other shock measures}

Figure A.1: Bernanke/Kuttner shocks
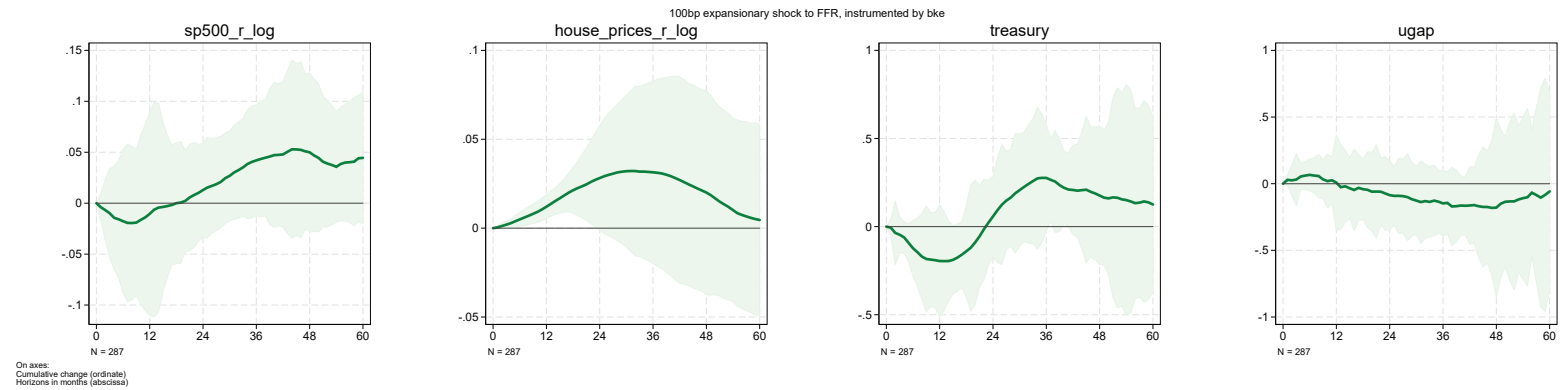

Figure A.2: Gertler/Karadi shocks
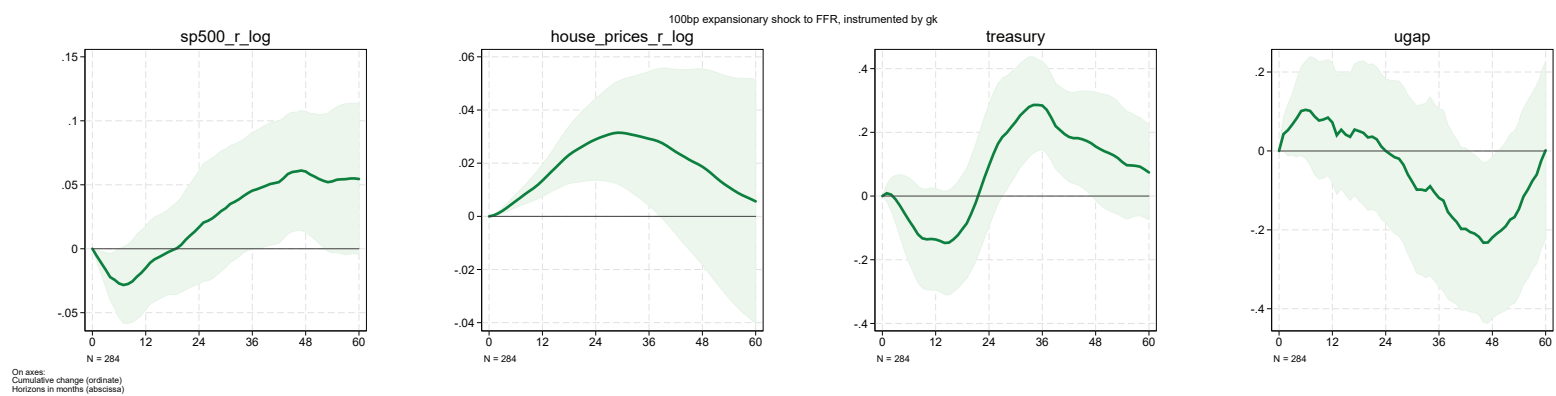

\section{A.2. Appendix: TVVAR Estimates}

Consider the structural form of the evolution of a set of macroeconomic variables and controls, $Y_{t}$, relative to a series of structural shocks, $\epsilon_{t}$ :

$$
H Y_{t}=C_{0}+\sum_{i=1}^{k} C_{k} Y_{t-k}+\epsilon_{t}
$$

Solving for $Y_{t}$ yields the following expression, in which $u_{t}=H^{-1} \epsilon_{t}$ represents reduced-form innovations which pick up the contemporaneous effects of the strucutrural shocks on all the variables within $Y_{t}$ :

$$
Y_{t}=B_{0}+\sum_{i=1}^{k} B_{k} Y_{t-k}+u_{t}
$$

The $\epsilon_{t}$ are not directly observable, so an external instrument related to the shock must be introduced. Let $\epsilon_{1, t}$ be the primary structural shock of interest, so that the instrument $z_{t}$ can be related as $z_{t}=\phi \epsilon_{1, t}+\eta_{t}$, where $\eta_{t}$ is normally distributed with mean zero and independent of all other 
Table A.1: Time-varying VAR responses following Paul (2020), 1pp expansionary shock

\begin{tabular}{lccccc}
\hline Shocks & Horizon & House Prices $(\%)$ & Stock Prices $(\%)$ & 1oY Treasury (pp) & Unemployment Gap (pp) \\
\hline $\begin{array}{l}\text { Paul (2020) } \\
\text { (2020) }\end{array}$ & & 1.4 & 13.85 & 0.24 & -0.11 \\
& $2 y$ & $(-3.1,5.82)$ & $(-0.99,29.48)$ & $(-0.76,1.29)$ & $(-0.61,0.34)$ \\
& \multirow{2}{*}{$3 y$} & $(-5.34,9.54)$ & $(-4.2,30.69)$ & $(-0.96,1.36)$ & $(-0.69,0.47)$ \\
& & 2.19 & 11.29 & 0.14 & -0.09 \\
& $4 y$ & $(-6.51,12.1)$ & $(-6.49,30.95)$ & $(-1.14,1.39)$ & $(-0.82,0.54)$ \\
& 2.14 & 10.64 & 0.13 & -0.06 \\
& & $(-8.03,14.24)$ & $(-8.69,31.45)$ & $(-1.24,1.5)$ & $(-0.88,0.62)$ \\
& 1.95 & 10.12 & 0.12 & -0.04 \\
& $(-9.02,16.24)$ & $(-9.84,32.93)$ & $(-1.37,1.67)$ & $(-0.93,0.73)$ \\
\hline
\end{tabular}

Notes: Approximate $9 \%$ Confidence Intervals in parentheses. Estimation includes monthly effective Federal Funds Rate and the unemployment rate in addition to variables shown. TVVAR method uses Gibb's sampling to uncover the distribution of responses over different time periods.

variables. We use the shocks calculated in Paul (2020) as our instrument. These can be directly integrated into the model as follows:

$$
Y_{t}=B_{0, t}+\sum_{i=1}^{k} B_{i, t} Y_{t-i}+A_{t} z_{t}+u_{t}
$$

